\title{
HISTORICKO-ARCHEOLOGICKÝ VÝZKUM DOBY TŘICETILETÉ VÁLKY (1618-1648). SOUČASNÝ STAV STUDIA A PERSPEKTIVY
}

\author{
MICHAL PREUSZ
}

\begin{abstract}
Abstrakt: S rozvojem archeologie konfliktu se do popředi zájmu dostává zejména výzkum bojišt', polních opevnění, obléhacich praci a táborů. Méně pozornosti archeologie věnuje systematickému studiu širšího socio-kulturního kontextu „velkých vojenských události“ "raného novověku. Předložená studie prezentuje současný stav a perspektivy archeologického studia stop, které zanechala třicetiletá válka ve středni Evropě v letech 1618 až 1648. Přináší základni informace nejen o bojištích, militárních pozicích a trendech ve výzkumu obětí války, ale poukazuje i na dlouhodobý zájem archeologů o zaniklé lokality a zánikové horizonty vžijicich sídlech. Díky dilčím lokálním výzkumům se daři studovat globální dopady války na širši sídelni sit', její zázemí, hospodářství a rozkrývat změny, jimiž válka poznamenala společnost i kulturu doby.
\end{abstract}

Klićová slova: archeologie konfliktu - třicetiletá válka - 17. století - bojiště - pohřby - města - vesnice hospodářství-depoty.

The historical and archaeological investigation of the period of the Thirty Years' War (1618-1648). The current state of research and its perspectives

Abstract: The development of conflict archaeology has brought to the fore, in particular, the investigation of battlefields, field fortifications, siege structures and military camps. Less attention has been devoted to the systematic study of the broader socio-cultural context of major military conflicts in the early modern age. This article presents the current state and perspectives of archaeological research concerning the traces of the Thirty Years' War in central Europe in the years 1618-1648. It brings basic information about battlefields, military positions and trends in the research into war casualties, and it also points out a longterm interest of archaeologists in deserted sites and desertion horizons in functioning settlements. Thanks to local investigations, archaeologists can study the global impact of the war on a broader settlement network, its hinterland and economy, and disclose changes in society and culture brought about by the Thirty Years' War.

Key words: conflict archaeology - Thirty Years' War - 17th century - battlefield - burials - towns - villages-economy-depots.

\section{1 Úvod}

Paralelně s formováním New Military History v historických vědách (srov. Prchal 2015, 25-81; Roberts 1967, 195-225) probíhá v historické archeologii etablování Conflict Archaeology. Oba proudy, které se vzájemně prolínají, vycházejí z teoretického konceptu „militární revoluce“, která zvyšuje atraktivitu současné moderní historie a archeologie vojenství zejména sledováním mocenských vztahů, jež lze vyjádřit jako svár politické, náboženské a kulturní dominance a rezistence (Bossen 2006, 89-102). Tradiční popisování přímočarých operačních dějin (např̀. bitvy, manévry, strategie) nahrazuje studium širších aspektů války z hlediska ekonomického (produkce, výměna, spotřeba), ideologického (morálka, estetika), militárního (agrese, defenziva) a politického (centralizace, institucionalizace a teritoriální ukotvení sociálních vztahů). Z pohledu procesuálního se raně novověká válka stala prostředkem k narušení a změně stávajících sociálních a kulturních struktur. Ty lze sledovat zejména díky studiu tzv. časových kapes (time capsules), jimiž jsou zejména zánikové horizonty, které dělí dobu na před a potom (ante quem a post quem; Jarvis 2003). Výsledkem změn bylo nastolení nového řádu a ukotvení nové struktury, poté co silnější porazí slabšího. Conflict Archaeology se tak stává epistemologickým deštníkem, pod nímž se v současnosti schovává nejen studium nejširšího spektra pramenů, obohacování současných přístupů o koncepty jiných vědních disciplín, ale především široká řada lokálních terénních výzkumů v krajině, zejména areálů konfliktů (bojiště, obléhací tábory), militárních pozic (polní ležení, pevnosti), sídelních a hospodářských struktur, které byly válkou poškozeny či zcela zničeny. Nejenže se otevírá nová cesta k poznání tradičních témat z jiného 
úhlu pohledu, ale studován je každodenní život všech sociálních vrstev na základě interakce historických a archeologických pramenů. Příklad lokálních studií týkajících se třicetileté války v konečném důsledku začíná přispívat $\mathrm{k}$ řešení nejen regionálních, ale i globálních problémů první poloviny 17. století (Orser 2008, 25-33; Preusz 2018). To činí z archeologie třicetileté války významnou součást archeologie novověku v ČR i v širším rámci Evropy (Žegklitz 2013, 53-69; Krajíc-Měřínský-Vařeka 2017, 367-399).

Přehled témat, jimž je věnována pozornost $\mathrm{v}$ historicko-archeologickém výzkumu doby třicetileté války v České republice, je uveden v tabulce níže, přičemž jednotlivá témata jsou prezentována $\mathrm{v}$ následujícím textu. Významné zahraniční lokality z doby třicetileté války, které jsou zmíněny dále, jsou vyznačeny na mapě č. 1 .

\begin{tabular}{|c|c|c|c|c|c|}
\hline & & & militární aspekt & bitvy a tažení & bojiště \\
\hline & & & (agrese a defenziva) & $\begin{array}{l}\text { (rozhodujici strety } \\
\text { moci) }\end{array}$ & polní tábory \\
\hline & & & & & polní opevnění \\
\hline & $\ddot{i} \cong$ & & archeologie bojišt' & pohřby & pohřby - anonymní aktéři \\
\hline & $\frac{0}{n} \bar{\Sigma}$ & & & (obèti války) & hrobky - konkrétní aktéři \\
\hline & है & & politika & sídla & vesnice \\
\hline & $\approx \check{E}$ & & $\begin{array}{l}\text { (centralizace, instituciona- } \\
\text { lizace a teritoriální ukot- }\end{array}$ & $\begin{array}{l}\text { (osídlení a sociální } \\
\text { diverzifikace) }\end{array}$ & města \\
\hline & 气 & & vení sociálních vztahů) & & tvrze \\
\hline & 21 & $\because$ & - & & hrady \\
\hline & $\frac{2}{2}$ & 总 & sídelní archeologie & & zámky \\
\hline 党 & 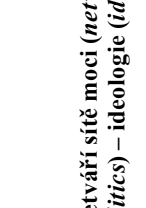 & 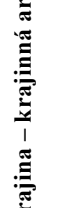 & $\begin{array}{l}\text { ideologie } \\
\text { (morálka, estetika) } \\
- \\
\text { archeologie ideologií }\end{array}$ & $\begin{array}{l}\text { ideologické stavby } \\
\text { (dominance a re- } \\
\text { zistence spole- } \\
\text { čenských hodnot. } \\
\text { vnímání prostředí, } \\
\text { náboženství) }\end{array}$ & $\begin{array}{l}\text { mocenské stavby } \\
\text { (pevnosti, paláce, hrobky } \\
\text { aj.) } \\
\text { religiózní stavby } \\
\text { (konfesijně diverzifikované } \\
\text { objekty) }\end{array}$ \\
\hline $\bar{~}$ & $\frac{0}{3}$ & 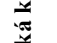 & ekonomie & řemesla & hrnčířství \\
\hline 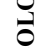 & $\stackrel{\mathscr{N}}{\mathbb{N}}$ & $\frac{\bar{c}}{80}$ & $\begin{array}{l}\text { (produkce, výměna, } \\
\text { spotřeba) }\end{array}$ & (regrese a růst) & kamnářství \\
\hline 뇔 & $>\overline{0}$ & 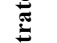 & & & sklářství \\
\hline$\frac{\pi}{4}$ & $\stackrel{\sqrt{*}}{=}$ & & & & výrobky z kovů \\
\hline & 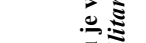 & & archeologie hospodářství & & zbrojní průmysl \\
\hline & $\stackrel{\Xi}{\Xi}$ & & & & $\begin{array}{l}\text { další hospodářství, např. } \\
\text { zemědělství }\end{array}$ \\
\hline & $\frac{\vec{E}}{\pi}$. & & & cennosti & mincovní nálezy \\
\hline & & & & & šperky a drahé kameny \\
\hline & & & & 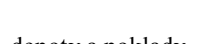 & depoty nádobí \\
\hline & & & & $\begin{array}{l}\text { (obranné strategie } \\
\text { obyvatelstva) }\end{array}$ & $\begin{array}{l}\text { další artefakty (zbraně, } \\
\text { řemeslnické nářadí aj.) }\end{array}$ \\
\hline & Výběr enviro & Iních & spektů ovlivňujících sociál & í a kulturní dění bě & m válečných let \\
\hline & klima (malá d & vá) & kolísání: snižování teplot / z & yšování vlhkosti & \\
\hline & energie a zdrc & viny) & regrese hospodářství, hledá & í nových zdrojů & \\
\hline & biodiverzita & & proměna skladby flóry a fau & & \\
\hline
\end{tabular}




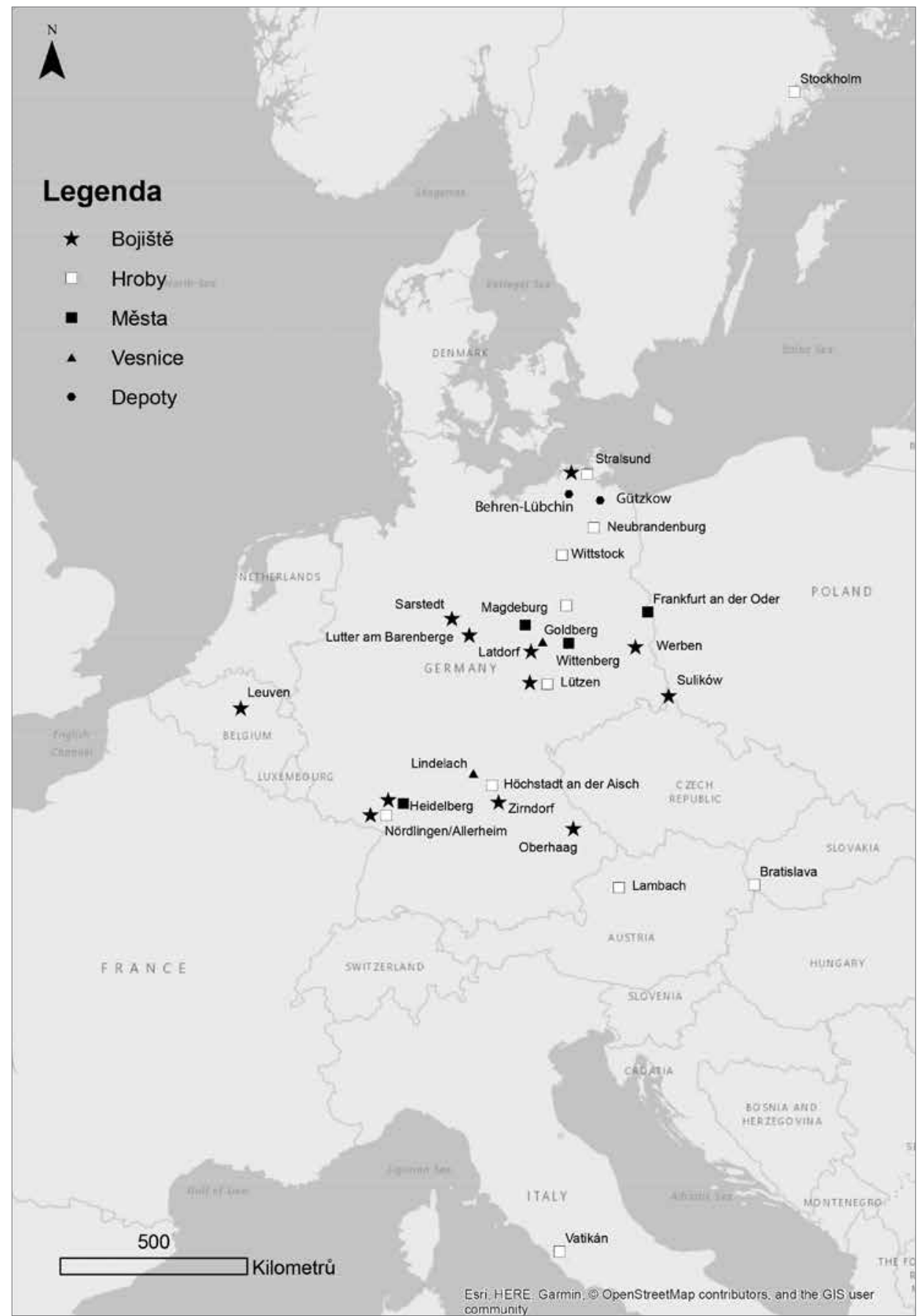

Mapa 1. Mapa zahraniěních lokalit z doby třicetileté války. (C) M. Preusz.

Karte 1. Karte ausländischer Fundstellen aus der Zeit des Dreißigjährigen Krieges. (c) M. Preusz. 


\section{Archeologie bojišt' a hrobů aktérů války}

Následující text podává informace o stavu výzkumu bojišt', militárních pozic, experimentálních výstavbách replik opevnění a o potenciálu výzkumu hrobů obětí války. Jednotlivé lokality jsou vyznačeny na mapě č. 2 .

\subsection{Archeologie bojišs'}

Bojiště vystupují jako jeviště války, na němž se konaly bitvy. Šlo o vrchol válečného divadla, kde evropské mocnosti proklamovaly svou politickou, ekonomickou či náboženskou dominanci nad nepř́itelem. Zájem o výzkum bojišt' $\mathrm{z}$ doby třicetileté války roste v mnoha evropských zemích. Velký přínos má především postupné etablování archeologické subdisciplíny, tzv. „archeologie bojišt'“ (Matoušek 2017, 233-243), v anglickém prostředí Battlefield archaeology (Sutherland 2005), v německém Schlachtfeldarchäologie (Brock-Homann 2011; Meller 2009), která se př́ímo orientuje na detailní výzkum širokého spektra pramenů týkajících se bitev, a to s využitím metod jiných vědních disciplín (historie, historické klimatologie, geografie, geologie, hydrologie, fyzické antropologie ad.) i s přispěním archeologického terénního výzkumu (nedestruktivními i destruktivními metodami) strategické krajiny (strategic landscape), v níž se bitvy odehrály (srov. Gojda 2013, 38-48). Očekávaným cílem je při tom postihnout faktory ovlivňující výběr místa (návrší, vodoteče, sítě cest, zalesnění, sociální faktory jako držba sídel, opevnění atd.) a za použití geografických informačních systémů se pokusit rekonstruovat digitální model reliéfu bojiště, do něhož je možné chronologicky vkládat informace o průběhu bojů, analýzy taktik a $\mathrm{v}$ rámci mikrotopografie vytvářet virtuální realitu. Dosud byl na různých úrovních započat v zahraničí výzkum bojišt' u Lutteru am Barenberge 1626 (Rodehorst 2014, 110-113), Lützenu 1632 (Schürger 2007; 2009, 22-25; 2011, 103-120; Grothe 2015, 386), Nördlingen 1635 a 1645 (Berg-Hohbohm-Wedekind 2008, 40; Berg-Hohbohm 2008, 21), Wittstocku 1636 (Eickhoff-Schopper 2012). Výsledky komplexních výzkumů Lützenu a Wittstocku, zejména s ohledem na objevy masových hrobů, byly prezentovány formou výstav ve Wittstocku a v Halle an der Saale (Meller-Schefzik 2015).

V českém prostředí sahají počátky dokumentace bojišt' třicetileté války do počátku 20. století, nebot' první prospekční návštěvy bojišt' doprovázené náhodnými nálezy a fotografickou dokumentací polních opevnění se konaly na bojišti u Rakovníka (Renner 1912) a ve švédském táboře u Staré Boleslavi (Zuman 1931, 5-17). V 60. a 70. letech pak následovaly výzkumy hromadných hrobů na Bílé hoře (Janská 1966, 107-110; Havel 1980, 227-230), kde se 8. 11. 1620 odehrála rozhodující bitva českého stavovského povstání, v níž byli povstalci poraženi. V posledních letech proběhl detektorový průzkum obory Hvězda v rámci asanace pěších komunikací. Získána byla kolekce projektilů (Bureš 2017, 245-259).

Systematický archeologický výzkum však začal probíhat až od sklonku 80. let 20. století, kdy započal výzkum bojiště u Třebele, kde se v roce 1647 strhla bitva mezi švédským a císařským vojskem. K výsledné publikaci došlo o více než 20 let později (Matoušek 2006) a v roce 2018 vyšla navazující publikace, v níž se mimo nové výsledky objevují i závěry z výzkumu bojiště u Teplé (srov. Matoušek 2018; Matoušek-Zimová-Janata 2012, 63-80). Poté se rozběhl výzkum dalších bojišt' (Matoušek 2012, 283-293).

Se jménem profesora Václava Matouška se pojí zejména studium plánů a krajinných panoramat bojišt', které byly prezentovány zejména v díle Theatrum Europaeum (Matoušek-Blažková 2012, 269-288). Tyto ikonografické prameny jsou určitým vodítkem pro detailnější prospekci terénu. Tímto způsobem byla analyzována krajinná panoramata bojiště na Bílé hoře 1620 (Altová a kol. 2010, 224-238) a u Jankova 1645 (Altová a kol. 2007, 589-633). Uveřejněny byly i analýzy plánů obléhání měst Brna (Matoušek 2011a, 609-621), Chebu (Matoušek-Boháč 2010, 449-466), Tábora (Blažková-Matoušek 2008, 849-869), Kolína (Soudná-Zimová-Matoušek 2010, 915-927), Olomouce (Fiedlerová-Matoušek 2012, 54-72) a Litoměřic (Drgáčová 2010, 19-22). Stejně tak byl detailně posouzen pohled na zámek Brandýs nad Labem (Matoušek a kol. 
2007, 93-148) a následně i plány měst v době mírové (Matoušek 2011b, 69-85). Vedle pohledů v Theatru Europaeu byla analyzována vybraná díla A. Sadelera (např. Rozvadov 1621), Václava Hollara, Karla Škréty (v případě obležení Prahy 1648) či některé mědirytiny z dobových letáků, např́íklad v případě obležení Plzně (Janata-Matoušek-Zimová 2013, 18-26; Mazanik 2012) či bitvy u Záblatí. Stranou archeologického zájmu zcela zůstávají malby, at' už jde o výjevy bitev P. Snayerse (k tomu napřr. Hrnčiřík 2005, 60-69), vyobrazení v denících jako u Jindřicha Michala Hýzrla z Chodů (bitva u Dolních Věstonic, na Bílé hoře, dobývání Loun; Petráňová 1979) nebo žánrové obrazy (Rousová 2007, 327-334).

Od 90. let se s pokrokem v oblasti vývoje detektorů kovů pozvolna rozvíjí i snaha systematicky vyhledávat kovové artefakty na bojištích. Tento přístup se dosud osvědčil zejména na bojišti u Rakovníka 1620 (Blažková 2011; Durdík 1976, 544-547, 599-600; Šámal 2018) a Rozvadova z roku 1621 (Braun 1995, 313; Kerscher 1994, 1-9; Procházka 1990, 6; Matoušek 2011, 3-13; 2013, 3-14). Díky tomu byly získány početné kolekce artefaktů z výzbroje, výstroje a vybavení vojsk a jejich doprovodu (Hrnčiř́ík 2011, 17-21; 2013, 17-32; Preusz 2017a, 170-186; Török 2011, 21-23; Dobrý 2011, 13-17; 2013, 15-16). Závěrečné vyhodnocení všech archeologických aktivit u Rozvadova bylo shrnuto v monografii z roku 2018 (Matoušek-Hrnčiřík-Šámal 2018).

Důležitou roli nejen na bojištích, ale také v otevřené strategické krajině zastávala opevnění, jež poskytovala obráncům útočiště a zároveň umožňovala kontrolovat okolí. Fenomén raného novověku představují polní opevnění budovaná ve stylu bastionového opevnění. V zahraničí byla pozornost kromě výše zmíněných bojišt' věnována fortifikačním systémům, např́iklad ve vojenském ležení u Latdorfu (Fahr-Nicklisch-Grothe-Döhle-Friederich 2015) a Zirndorfu 1631 (Mahr 1980; 1982; Kesrcher 2006), obléhacímu táboru u Heidelbergu 1622 (Straßburger 2007, 247-250; 2007a, 56-61; 2009, 143-146), vojenskému ležení podél řeky Labe u Werben 1631 (Klamm-Stahl 2015), Sarstedtu u Hildesheimu (Cosack 2006, 241-252) či v belgickém Leuven z roku 1635 (Brion 2014). Pozornost byla věnována i opevněním na bavorské straně Českého lesa a Šumavy, např́íklad u Oberhaagu (Krenn 1989, 277-278; Krenn 1992). Přibližovací sapy z roku 1628 byly zkoumány u Stralsundu (Ansorge 2007, 37-40). V Polsku byl lokalizován opevněný tábor u Sulikòwa (osobní sdělení G. Podruczny).

V České republice roste zájem o výzkum novověkých polních fortifikací (Matoušek 2015, 70-82). Studovány byly zejména polní fortifikace na bojišti u Třebele, u Rozvadova, pak jednotlivá opevnění, která byla budována k zajištění zemských hranic a hlavních komunikací. Patří sem např́íklad Volarské šance na Zlaté stezce (Beneš-Kubů-Török 1995, 461-480; Fröhlich 1996, 519-521), opevnění u Železné na Řezenské cestě (Kerscher 1998, 423-448), u Bärnau na Zlaté cestě (Busl 2003, 345-346; Kinder 2013, 270-272), u Kynžvartu na cestě z Chebska do Plzeňského kraje (Kovandová-Matoušek 2004, 61-66; Rožmberský 1991, 9-11), šance u Hradce nad Moravicí a Jablunkovské šance na cestě ze Slezska do Uher (Krůl-Nováková 2005; Krůl 2013, 113-119; 2017, 561-577). Celá řada opevnění byla dokumentována také na jihočeské hranici (Fröhlich 2000, 285-290). Další opevnění jsou postupně vyhledávána ve vnitrozemí, v blízkosti velkých měst, kde opanovala území, cesty či sloužila k obléhání. Mezi takové fortifikační stavby patř́i polohy u Klatov (John 2012, 33-36), Pelhřimova (Kováŕ 2014, 218-226), Olomouce (Martínek a kol. 2013, 235-236), Horních Moštěnic (Macků 2015, 111-114), Chrudimi (MusilNetolický-Preusz 2018, 299-300), Tábora (Krajíc 2007, 145, obr. 1), Lokte (nepubl. výzkum NPÚ Loket: Prekop 2016), na Lhenicku, v okolí Českých Budějovic (Konrádová 2017, 77-84; Konrádová a kol. 2017, 261-277) či u Zvíkova (Fröhlich 1991, 155-159; Kypta-Richterová 2004, 253-260). Pozornost byla věnována švédskému táboru u Staré Boleslavi (Waldhauser 2009a, 939-964; Zuman 1931, 5-17). Památkou na obléhání Brna v roce 1645 jsou přibližovací zákopy a sapy (Loskotová 1997, 309-313; Loskotová-Hanák 1995-1996, 143-151).

Specifikou české archeologie je snaha ověřovat informace zjištěné jak v archivech, tak $\mathrm{v}$ terénu formou experimentů. Za tímto účelem byly provedeny experimentální stavby redut u Olbramova na západočeském bojišti u Třebele (Matoušek 2004, 260-277; 2006, 115-132) a posléze ve východočeském Uhřínově (Dragoun-Matoušek-Tuček 2007, 61-66), které měly 
napomoci objasnit časovou a technickou náročnost výstaveb opevnění. S odstupem času jsou na opevněních pozorovány sukcesní procesy jednotlivých částí opevnění (Matoušek 2015, obr. 6).

Za dosavadního pojetí archeologie bojišt' se částečně do pozadí zájmu dostává okolní krajina (zázemí a místo plundrování). To ukázala v posledních letech jednak zjištění polních fortifikací ve vnitrozemí, ale i detektorový průzkum zaměřený na získání švédských vojenských oděvních spínadel v transektu, který se táhl od Chrudimi přes Pardubice po Hradec Králové (Musil-Netolický-Preusz 2018, 285-292).

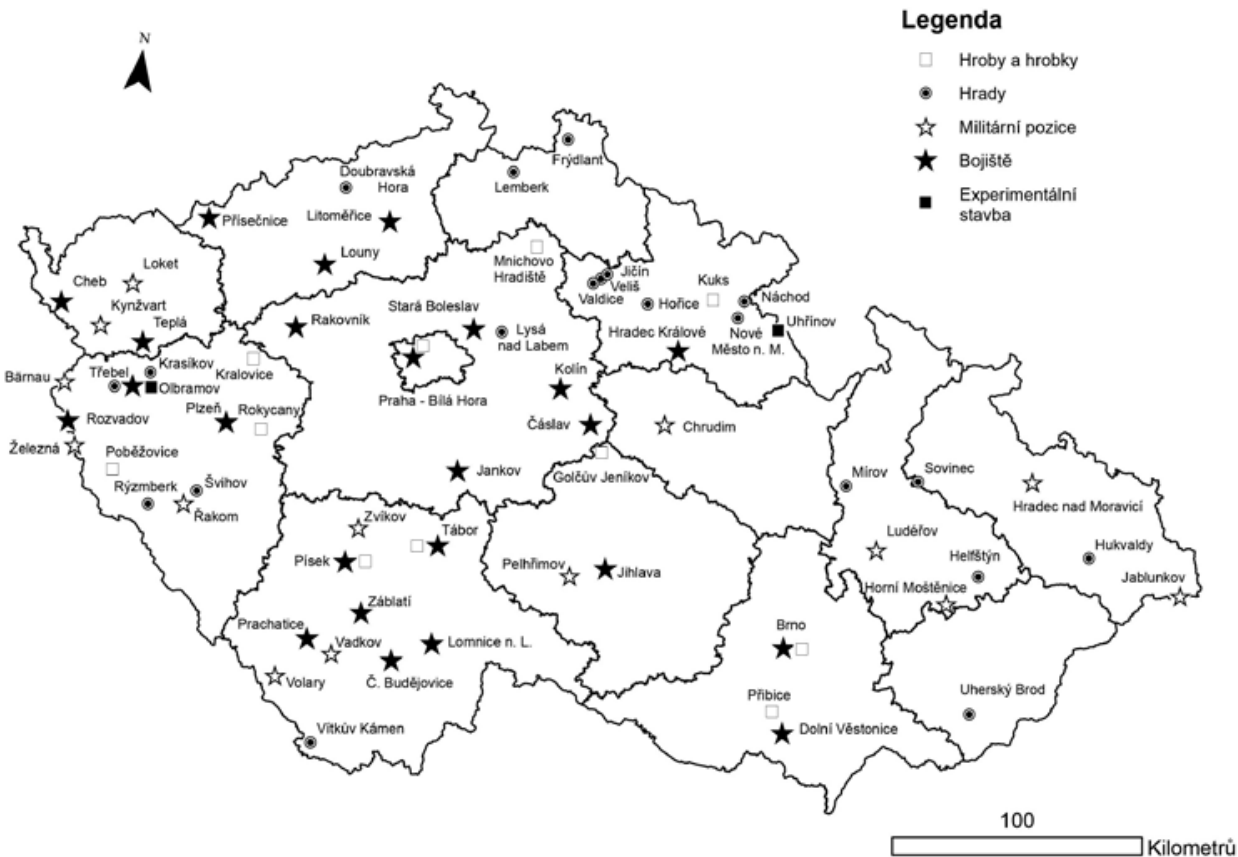

Mapa 2. Mapa bojišt', militárních pozic, hradů, experimentálních staveb, hrobů a hrobek souvisejících s třicetiletou válkou na území současné ČR. (C) M. Preusz.

Karte 2. Karte mit Schlachtfeldern, militärischen Stellungen, Burgen, experimentellen Bauten, Gräbern und Gruften, die mit dem Dreißigjährigen Krieg auf dem Gebiet der heutigen Tchechischen Republik zusammenhängen. (c) M. Preusz.

\subsection{Pohřby}

Výzkum pohřbů, které souvisí s třicetiletou válkou, lze rozdělit do dvou směrů. Prvním je výzkum hromadných (masových) hrobů, druhým výzkum řádných pohřbů, zejména pohřbů významných osobností. Oba dva výzkumy cílí k poznání válečné populace, zejména ve spolupráci s fyzickými antropology, proto vedle studia pohřebního ritu přibývají analýzy kosterních pozůstatků za účelem studia stáŕí a pohlaví jedinců, úrovně jejich výživy, jejich nemocí, zranění a dalších anomálií, jež souvisí s válečným děním (např. jízda na koni, nošení zbroje). V některých případech bylo dokonce přikročeno k rekonstrukci původní podoby vojáků. Studovány jsou také artefakty v hrobech, oděvy, oděvní doplňky a šperky, zbraně aj. Ve spolupráci s historiky a historiky umění lze studovat také fenomén pohřbívání významných válečníků v hrobkách, 
s čímž souvisí také perspektiva studia epitafů, náhrobků a nejrůznějších symbolických doplňků hrobových míst (zbroj, zbraně apod.). ${ }^{1}$

Hromadné hroby a hroby jednotlivců jsou detekovány zejména v místech přímých vojenských akcí, kdy byl nedostatek času k řádnému pochování lidí či jejich tělesných ostatků a údy byly zpravidla $v$ rychlosti naházeny do hrobových jam. Někdy byla tato místa označována pomníky (např. Parkan 2008, 21-23). V zahraničí proběhlo od 80. let 20. století několik výzkumů tohoto charakteru - velký počet souborů zpracovala Bettina Jungklaus. Zejména to jsou výzkumy pobitých sedláků v rakouském Lambachu z roku 1626 (Pertlwieser 1996, 49-59), mrtvých Švédů v Brandenburg an der Havel z roku 1631 (Dalitz-Grupe-Jungklaus 2012, 67-80; Jungklaus 2012, 132-135), obětí obléhání města Neubrandenburg vojskem Tillyho v roce 1631 (Jungklaus-Prehn 2011, 10-33), obětí na bojišti u Lützenu 1632 (Friederich-Schröder 2015, 399-404; Nicklisch-Knipper-Held-Pickard-Ramstahler-Friedrich-Kurt 2015, 405-420; Le $\beta$ mann-Dittrich 2015, 427-428), mrtvol objevených v suterénu jednoho z domů v bavorském Höchstadt an der Aisch (Plum 2012, 393-402; Wangerin 1986, 157-159), ostatky jezdců z první bitvy u Nördlingen 1634 (Plum 2012), hromadný hrob obětí z bitvy u Wittstocku 1636 (EickhoffJungklaus 2012) a hromadný hrob z druhé bitvy u Nördlingen v roce 1645 (Misterek 2012, 361391). Tento výčet pak doplňuje nález vojáků pobitých v obléhacích zákopech směřujících k městu Stralsund z roku 1628 (Ansorge 2010, 122-135; Jungklaus-Konze-Samariter 2012, 98-103). Na Slovensku byl identifikován hrob Valonů z bratislavské vojenské posádky, kteří byli povražděni u dnešního Blumentálu v roce 1621 (Vyčíslík 1974, 81).

Patrně nejstarší hromadný hrob související s třicetiletou válkou v Čechách byl objeven ve městě Písek. Souvisí s obléháním města císařským vojskem v roce 1619 (Fröhlich 2010). Během tažení ku Praze pak ztratila císařská vojska dva vojáky u Kralovic. Jeden z nich měl u sebe kožený váček se 476 drobnými mincemi. Ta nejmladší byla z roku 1620 (Nohejlová-Prátová 1957, 218-221). Hromadné hroby byly zkoumány také na Bílé hoře u Prahy, kde se strhla bitva 8. listopadu 1620 (Janská 1966, 107-110; Havel 1980, 227-230). V Táboře byly identifikovány hroby vojáků, kteří padli patrně při obléhání města v roce 1621 (Krajíc-Mořkovský 2005, 397-416; nový nález z roku 2018 na www.technet.idnes.cz). V roce 1900 byly údajně nalezeny lidské ostatky a pouta $\mathrm{v}$ místě mohyly Mandlonova pluku, který byl v Rokycanech zdecimován na prŕíkaz arcivévody Leopolda Viléma Habsburského (Hrachová 2011, 84-86). Výčet uzavírá průzkum pohřebiště v předpolí Pražského hradu, na němž byli v roce 1648 pochováni švédští vojáci (Blažková-Dubská 2005, 403-408). V roce 2018 bylo prozkoumáno pohřebiště novokřtěnců v moravských Přibicích (reportáž ČT24 ze dne 24. 8. 2018).

Kromě výzkumu hromadných hrobů se orientuje výzkum na ostatky známých, zpravidla významných osobností, panovníků a vojevůdců. V zahraničí byl dosud proveden výzkum tělesných ostatků královny Kristýny Švédské (1626-1689), které jsou uloženy v hrobce v chrámu sv. Petra a Pavla ve Vatikánu (Hjortsjö 1966). V Čechách sahá tradice antropologického výzkumu dokonce do 20. let 20. století, kdy byly publikovány první výsledky antropologického průzkumu ostatků Albrechta z Valdštejna, jehož tělo spočinulo v Mnichově Hradišti. Antropologické průzkumy ostatků významného válečníka se pak ještě několikrát opakovaly (Matiegka-MalýBergl 1934; Šimák 1922/1923, 153-158; Vlček 1976, 678; 1993, 234-267). V 60. letech přibyl výzkum ostatků Jeana Louise Raduita de Souches, velitele obrany města Brna proti Švédům v roce 1645 (Novotný 1967, 56-57). V posledních letech byly antropology zkoumány v rodové hrobce v Kuksu ostatky císařského generála Jana Šporka, který žil v letech 1595 až 1679 (Velemínský-Dobisíková-Kuželka 2000; 2001), v Golčově Jeníkově ostatky císařského generála Martina Maxmiliána z Golče, jehož život spadal mezi léta 1593 až 1653 (Sládek a kol. 2010). Méně často jsou zkoumány pohřby jednotlivých neznámých vojáků, jako tomu bylo v případě průzkumu hrobů v kostele sv. Petra v Niedertraublingu, kde byly nalezeny ostatky vojáka, jenž měl při

1 Perspektivy tohoto směru bádání naznačila přednáška o epitafech válečníků v českých zemích s názvem „Sepulkrální/memoriální památníky a jejich proměny v kontextu třicetileté války (Sepulchrale/memoriale Denkmale und ihre Verwandlungen im Kontext des Dreissigjährigen Krieges )“, která zazněla z úst Ondřeje Jakubce na konferenci Třicetiletá válka v českých zemich. Doba. Události. Lidé. Kultura, která proběhla ve dnech 14.-16. 11. 2018 v Plzni. 


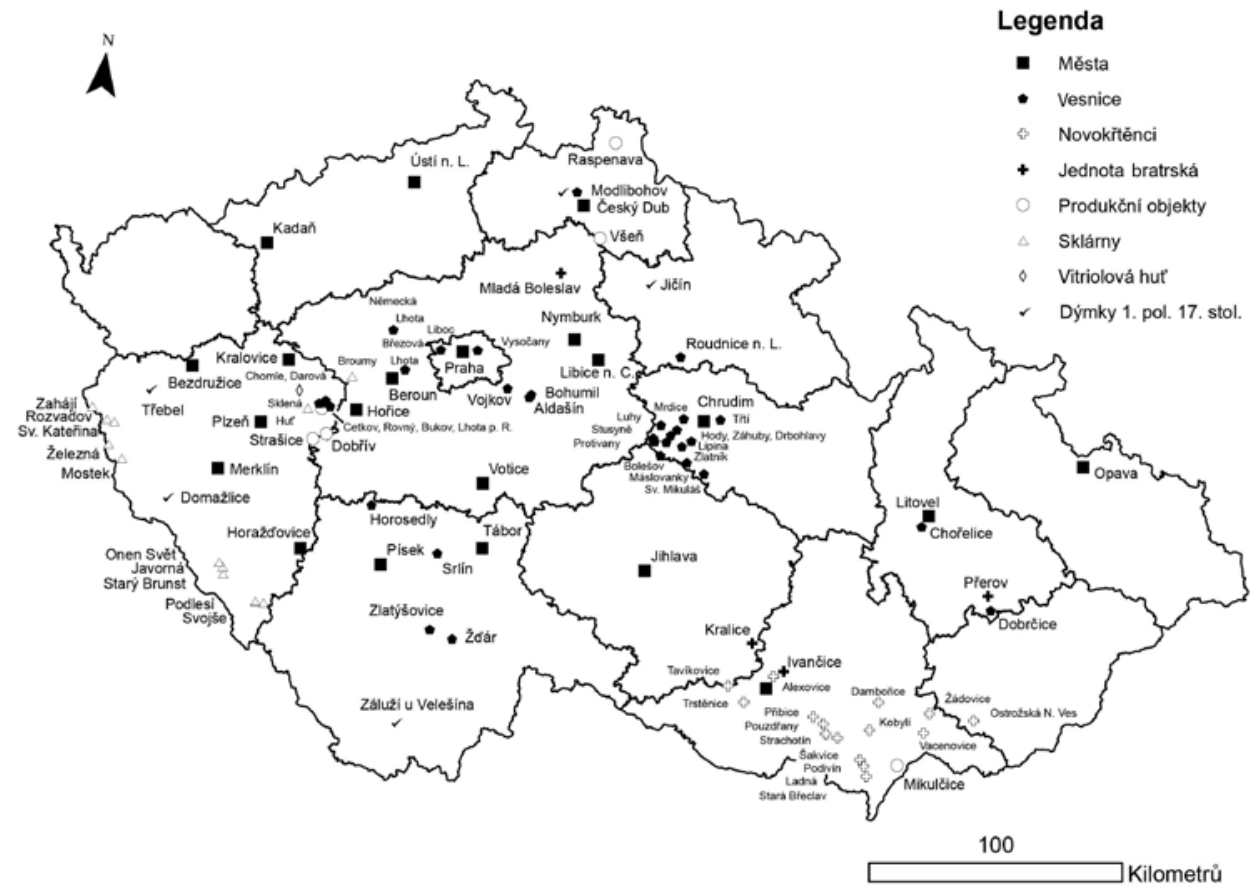

Mapa 3. Mapa městských horizontů, vsí, novokřtěneckých areálů a lokalit spjatých s Jednotou bratrskou, skláren, specifických výrobních zařízení, vitriolových hutí a nálezů dýmek z 1. poloviny 17. století. @ M. Preusz.

Karte 3. Karte mit den Horizonten von Städten, Dörfern, mit den Böhmischen Brüdern verbundenen Wiedertäuferarealen und Fundstellen, von Glashütten, speziellen Produktionsanlagen, Vitriolhütten und Pfeifenfunden aus der ersten Hälfte des 17. Jahrhunderts. () M. Preusz.

sobě uloženy ostruhy a rapír vyrobený mezi lety 1600 až 1630 (Codreanu-Windauer 1988, 150; 1993/1994, 285). V kontextu pohřbů známých osobností lze upozornit na ještě nevyhodnocený průzkum hrobky Jana Jiřího ze Švamberka v Poběžovicích, který proběhl 26. června 2018. ${ }^{2}$

\section{Sídelní archeologie}

V následující části článku bude pozornost věnována zejména městům, vsím, hospodářským provozům a jiným lokalitám. Jednotlivé lokality jsou vyznačeny na mapě č. 3.

\subsection{Města}

Jelikož historická jádra měst patří mezi archeology nejdetailněji zkoumaná prostředí, má výzkum dopadu třicetileté války na města velký potenciál, který však dosud nebyl plně využit. Nutno podotknout, že situace související s válkou jsou zpravidla prezentovány jako součást komplexnějších studií, které pojednávají o stavebně historickém vývoji vybraných staveb, méně pak samostatně. Tento př́stup pak velmi znesnadňuje heuristiku literatury, která se tématu týká. Ve Švédsku je fenoménem studium restrukturalizace a proměny měst v důsledku ekonomického růstu země v novou mocnost. S tím souvisí de facto výzkum raně novověkého města jako celku (fortifikace, uliční sítě a náměstí, nové domy, hospodářské zázemí, přístavy ad.), který vyrůstá 
téměř zcela nově a nahrazuje středověké formy. Našemu prostř̌edí je pak blíž spíše výzkum zánikových horizontů, který probíhá v Německu. V evropské urbánní archeologii jsou zatím zkoumány zejména zánikové horizonty. Takové výzkumy byly provedeny např́iklad v Heidelbergu 1622, Frankfurtu nad Odrou, Magdeburgu 1631 (Grothe-Weber-Ditmar-Trauth-DitmarTrauth-Huthmann-Köther 2015, 449-452) aj.

Dosud nebyl vytvořen zcela přesný seznam zánikových horizontů z třicetileté války, jež byly archeologicky prozkoumány v městském prostředí v Čechách, na Moravě a ve Slezsku. Je to dáno zejména častým upozaděním raně novověkých situací na úkor většího zájmu archeologie o starší období. Výzkum měst za třicetileté války pozvolna nabírá dva směry. Jeden se pod vlivem stavební historie zabývá proměnou „nadzemni“ podoby měst, zejména směřuje k poznání fortifikačních systémů, růstu městských paláců, restrukturalizaci církevní architektury. Druhý cílí přímo na zánikové horizonty, které pochází zejména ze zcela zdemolovaných domů a domovních traktů, řemeslnického zázemí apod. Do této sekce patří zaniklé předměstí v Berouně (Matoušek-Scheufler 1980, 53-57; 1983, 189-196; Matoušek-Scheufler-Štajnochr 1985, 126-139; Vařeka 2004, 78-85; Vyšohlíd 2015, 411-430), planýrovací vrstvy na náměstí v Bezdružicích (Zelenka 2016, 213-229), zničené městské domy na náměstí v Horažd’ovicích (výzkum Archaia Jih: Kašák 2016, nepubl.), spálené domy v Hořovicích (Koucký-Stolz-Stolzová 2004, 787-799), Chrudimi (Frolík-Musil 2010, 3-28; Musil 2010, 181-190; 2016; Sigl 1995, 61-72), spálená bašta v Kadani (Derner 2018, 145-161), zasypané studny z Klatov (Vondráčková 1996, 134-156), objekt hospodářského charakteru v Litovli (Hlubek-Šlézar 2016, 51-65), planýrovací vrstvy v Merklíně (Bouda-Kočár 2011, 35-36; Preusz 2017, 35-36), zaniklá sladovna v Nymburku (Motyková 2003b, 772, 775, obr. 6:9, 6:10; Sedláčková-Brožková-Stará 1997, 28-30), patrně zničená hrnčířská dílna v Opavě (Šikulová 2004, 19-28), zásypy sklepů zničených domů v Písku (Jiřík a kol. 2016, 47-79), márnice v Plané (Rayman 2014, 121-130), zásypy studní v pražském domě lékaře Matyáše Borbonia z Borbenheimu, který byl osobním lékařem císaře Rudolfa II. Habsburského (Huml 1995), zásypy studní městských a předměstských domů v Ústí nad Labem (Cvrková-Černá 2007, 77-90), požárové vrstvy ve Voticích (Hušták 2012, 36-37). V Plzni byly odhaleny relikty špitálu sv. Máří Magdaleny, jehož definitivní zánik souvisel s obléháním města na podzim 1618, kdy nechal velitel obrany Felix Dornheim spálit předměstí a mezi nimi tedy i tzv. Pražské předměstí. Př́ímo tudy kolem špitálního kostela zaútočilo vojsko generála Petra Arnošta z Mansfeldu (1580-1626). Při archeologickém výzkumu bylo objeveno spáleniště, které obsahovalo velké množství mazanice a keramiky 17. století (Dudková-Orna-Netolický 2015, 19-20, obr. II.13-14). Další nálezy z doby třicetileté války pochází z domu čp. 289 na náměstí (Dudková-Orna 2009, 501-508; Ježek-Zavřel 2010, 608-628). Banérova taktika spálené země byla praktikována v širokém pásu. V letech 1639 a 1640 byla důsledně vypálena Libice nad Cidlinou, v níž byly archeologicky prozkoumány spáleniště dvou manských dvorů. Získána byla kolekce kachlů, keramiky, kuliček, železných předmětů a skla, bronzový plíšek a kostěný roubík (Princová-Justová 2000, 241-254; Justová 2002, 381-392).

\subsection{Vesnice}

V rámci sídelní archeologie se rozvíjí rovněž výzkum vesnic, které prošly třicetiletou válkou (srov. Symonds-Vařeka 2016, 129-145). I zde se bádání ubírá dvěma směry. Prvním je výzkum zcela zaniklých vesnic. U nich je dokumentováno půdorysné rozvržení vsí, původní rozvržení usedlostí a jejich půdorysné a vnitřní členění, dále hospodářsko-provozní zázemí v podobě plužin, zahrad, komunikací, těžebních areálů a výrobních zařízení. V druhém případě jde o výzkum v intravilánech dosud žijících vsí, kde jsou zpravidla zkoumány strukturální proměny po válce.

S výzkumem vesnic se dále úzce pojí stavebně-historický průzkum staveb první poloviny 17. století (Dörfler-Stiewe 2010, 15-23). Přínos má i studium dřevěných konstrukcí dendrochronologicky datovaných do období třicetileté války. Porovnáním složení druhů ve válečných a poválečných stavbách lze vypozorovat rozdíly $\mathrm{v}$ pestrosti využívaných druhů dřevin. Válečné 
stavby jsou výrazně chudší na druhové složení, nebot' lesy pustly a nastal úpadek lesních řemesel. Teprve po válce došlo k obstarávání rozmanitého sortimentu dřev odlišného druhu a původu (např. Marstaller 2008, 83-84). K výzkumu vesnic patří rovněž studium vybavení vesnických usedlostí, které doplňuje výsledky studia pozůstalostních inventářů (Petráňová-Vařeka 1987, 277-286). V zahraničí byla dosud komplexně zkoumána např́iklad vesnice Goldberg v Sasku-Anhaltsku (Paddenberg 2015, 441-442) či Lindelach v Horní Falci (Michl 2017).

V návaznosti na tradiční výzkum vesnického prostředí ve středověku se od 70. let 20. století začal rozvíjet výzkum vesnického prostředí v raném novověku také v českém prostředí. První cílený výzkum vesnice, která zcela zanikla v průběhu třicetileté války, byl proveden u Kladna. Na základě studia Soupisu škod pro panství Smečno z let 1631 až 1648 byla vytipována a lokalizována ves Německá Lhota. Zprvu šlo o geodeticko-topografický průzkum areálu vsi, přičemž posléze byla sondována zaniklá usedlost (Richterová 1981, 475-479; 1982, 247-252; Smetánka 1970). Následně se rozběhl výzkum zaniklých vsí na Černokostelecku. Zprvu zde byly zkoumány jednotlivé vsi, zejména s akcentem na otázky týkající se jejich vzniku, jako Aldašín (Klápště 1978; Smetánka-Klápště 1981; Vařeka 2006; Malina 2013), Bohumil (Klápště 1978; Smetánka-Klápště 1981), Cukmantl (Klápště 1978; Smetánka-Klápště 1981). S výzkumem Vojkova (Kodera 2009, 55-62; Vařeka 2009, 43-54; 2010, 147-181) se započalo s komplexněji pojatým hledáním odpovědí na příčiny zániku vsí během třicetileté války, což vyvrcholilo ve snahu pozorovat vývoj a změny celého mikroregionu. Začaly být detailněji studovány př́rodní a sociální faktory, které měly vliv na zanikání sídel během třicetileté války východně od Prahy. Od 90. let začaly pozvolna přibývat další a další jednotlivosti roztroušené po Čechách a Moravě. Například v jižních Čechách výzkum v Srlíně (Dohnal-Vařeka 1997, 84-106) a v Horosedlech na Písecku (Jiř́ík a kol. 2010, nestr.), zaniklých Zlatýšovic u Hluboké nad Vltavou (Čapek 2011, 365-367). Další poznatky souvisely s výzkumy v dnešní Praze, kde byly sondovány zaniklé usedlosti v Liboci (Bureš 2003, nestr.) a Vysočanech (Bureš 2002, nestr.). V severních Čechách byl zkoumán zaniklý mlýn v Modlibohově (Tišerová-Stará 2007, 254-258), ve východních Čechách byl detekován zaniklý dvůr v Roudnici nad Labem (Muzeum východních Čech v Hradci Králové, nepubl.).

Další významný výzkum mikroregionu probíhá na Rokycansku (Vařeka a kol. 2006), a to zejména na císařském panství Zbiroh. Zde jsou zkoumány zcela zaniklé vsi Bukov (Vařeka 2016, 156-167), Cetkov (Dudková-Orna-Vařeka 2008; Veselá 2006, 67-98) a Rovný (Vařeka 2014, 131-143). V posledních letech se detailně mapuje venkovské osídlení na Chrudimsku, zejména vsi Bolešov (Musil-Netolický 2012, 73-114), Drbohlavy, Hody, Lipina, Luhy, Máslovanky, Mrdice, Svatý Mikuláš, Stusyně, Třtí, Záhuby, Zlatník aj. (Musil-Netolický-Preusz 2018, v tisku). $\mathrm{S}$ bádáním kolem vsí souvisí také výzkum hospodářského zázemí velkostatků. $\mathrm{V}$ posledních letech byl detailně studován např́íklad ovčín Žár ve Velechvínském polesí u Hluboké nad Vltavou (Čapek-Preusz 2012, 6-35), momentálně probíhá průzkum zničených rybníků a rybničních soustav na Zbirožském panství.

Na bádání o zaniklých vsích a venkovských usedlostech navazuje snaha o poznání procesu revitalizace venkova po válce, resp. snaha o nalezení příčin toho, proč některá místa zcela zpustla a jiná byla naopak znovu využívána či obnovována. Jde zejména o výstavbu hospodářských dvorů, přerozdělování polí, obnovu rybníků, obnovu lesů poničených překotnou železářskou výrobou apod. V tomto kontextu má svůj nezastupitelný význam také kombinovaný stavebně-historický průzkum s archeologickým výzkumem stojících vesnických objektů, v nichž se mnohdy objevují kontexty související více či méně s válkou, jako např́iklad v Čisté či Sebranicích (Merta-Kolařík-Kmošek 98-113; Kolařík-Merta-Pokorný 2014, 211-220; Kolařík-Merta-Peška 2015, 9-26).

\subsection{Náboženská válka}

Zejména v německy mluvících zemích se dlouhodobě rozvíjí výzkum zaměřený na řešení konfesijních otázek, proto se začalo hovořit o archeologii reformace (Ring 2013, 167-183; 
Scholkmann 2007, 3-25) a protireformace (Mittelstraß 2007, 9-20). Výzkum se zaměřuje na výzkum katolických a protestantských sakrálních staveb, výzkum devocionálií (např. Králíková 2004), náboženské motivy ve výzdobě kachlů (Žegklitz 2012, 25-111), skla, keramických artefaktů atd. Třicetiletá válka se stala vyvrcholením náboženských sporů probuzených během 16. století.

Na jižní Moravě je dlouhodobě věnována pozornost výzkumu heretické skupiny novokřtěnců, resp. habánů. Tato sekta vznikla roku 1524 ve Švýcarsku a postupně se přesunula na Moravu. Z ní byli, pro své neuznávání křtů dětí a prosazování křtu v dospělosti, vyhnáni vítěznými katolíky ve válečném roce 1622 . Z archeologického hlediska je velká pozornost věnována výzkumu jejich usedlostí, hrnčířským produkčním centrům a výrobě speciální novokřtěnecké fajánse. Tento výzkum se na Moravě rozvíjí od předválečného období a je nedílně spjat se jmény Karla Černohorského (Černohorský 1931; 1941; 1952), Heřmana Landsfelda (Lansfeld 1950; 1953; 1956; 1971a; 1971b, 1976) a Jiřího Pajera (Pajer 1974, 169-184; 1982; 1983; 2006; 2011).

V českých zemích působila od roku 1457 Jednota bratrská, která se postupně zařadila mezi protestantská vyznání a stala se významnou složkou předbělohorské společnosti. Její úpadek nastal po bitvě na Bílé hoře v roce 1620 . Tuto skutečnost doložily některé archeologické výzkumy. Odhalení bratrské tiskárny v Kralovicích nad Oslavou v roce 1956 je spjato se jménem Vlasty Fialové. Průzkum v kralické tvrzi se stal světově významným, nebot' zde byla prozkoumána tajná tiskařská dílna z let 1562 až 1619, v níž moravští bratři vytiskli Bibli kralickou (např. Fialová 1958, 3-16; 1959, 85-91; 1961, 136-141; Chaloupka 1977, 13-18). V 80. letech byl publikován hromadný soubor zlomků keramicky, kachlů, skla atd. ze studny z areálu bývalého bratrského sboru v Ivančicích (Šebela-Vaněk 1985). V roce 2012 proběhl výzkum bratrské školy v Přerově, která byla založena roku 1554 a v období rekatolizace byla přestavěna na katolický kostel sv. Marka. Kostel vyhořel v letech 1664 a 1749, poté již nebyl obnoven. V letech 1614 až 1618 v bratrské škole působil Jan Ámos Komenský (nepubl. www.prerovsky.denik.cz). S působením Sboru českých bratří v Čechách souvisí nález malované dřevěné bedničky, v níž bylo uschováno zhruba 400 ks písemností, $\mathrm{k}$ němuž došlo při odkrývání zásypů cihlových kleneb v areálu Karmele v Mladé Boleslavi. Nalezena byla korespondence Matouše Konečného z let 1605 až 1620/1622, soupisy členů sboru z několika míst a další nespecifikované archiválie. Zajímavostí bylo objevení dopisu Václava Budovce z Budova, který byl popraven na Staroměstském náměstí v Praze v roce 1621 (Waldhauser 2009, 42-43).

\subsection{Rezistence a dominance}

Vítězná císařská generalita se snažila své nové společenské postavení na dobytém území legitimovat, k čemuž jí mělo pomoct přivlastnění si dobytého území. Stejně jako za dob feudalismu hrála pozemková držba, získaná panovnickou odměnou, konfiskátem či cíleným nákupem, klíčovou roli. Teprve obdržením pozemkového vlastnictví mohl vstoupit generál mezi privilegovanou zemskou šlechtu a první polovina 17. století byla právě dobou, kdy k výměně šlechty došlo. Řada starých šlechtických rodů vymřela. Řada přistoupila po bitvě na Bílé hoře v roce 1620 k nucenému exilu. Došlo k vzestupu nových osobností, které vsadily na vojenskou kariéru a zvítězily (Buquoyové, Collaltové, Colloredové, Gallasové, Leslieové, Magnisové, Morzinové, Piccolominiové, Trauttmansdorfové aj.). Vedle právního ukotvení vlastnictví však bylo nutné prezentovat důležité šlechtické hodnoty, jimiž byla hloubka a tradice, což řešila šlechta finančním mecenátem. Jako protiklad k válečnému ničení začali válečníci ukotvovat svou pozici fundacemi nových raně barokních paláců, sakrálních staveb, poutních míst a přestavbami starých staveb (srov. Panochová 2006, 492-503; Gaži 2005, 65-74; Forbelský 2006, 591-598; Kilián 2010, 179-193), přičemž formou kulturního mecenátu podporovali zejména výzdobnou prezentaci vojenských úspěchů svých i svých předků, což bylo př́iznačné pro Františka Antonína Šporka v Lysé nad Labem, hrabata z Bredy na Lemberku, Waltra Leslieho v Novém Městě nad Metují, Ottavia I. Piccolomiho v Náchodě ad. (Prchal 2015, 254-278). 
V podobném kontextu může být architektura první poloviny 17. století chápána jako symbol rostoucí nadvlády vítězné generality na dobytém území, přičemž je tím potlačováno pưvodní sociální postavení poraženého protivníka, utvářeno nové privilegované postavení vítěze a formují se vztahy k novým poddaným, kterým je vnucován nový hodnotový systém. Fundace a přestavby sakrálních staveb a poutních míst byly nástrojem rekatolizace. Ukázkou identifikace nové šlechty s nově nabytým sakrálním prostorem jsou nové rodinné hrobky a hroby. Mimo případy uvedené u pohřebišt' lze v novém prostoru pozorovat např́íklad ostatky Linnharta Colony z Felsu, který byl zabit švédskými vojáky ve své tvrzi v Koutě na Šumavě roku 1648. Jeho tělo bylo pochováno v centru koutského panství v Nové Kdyni pod hradem Rýzmberk.

Fortifikační architektura nejenže měla militární funkci, nýbrž také symbolicky upozorňovala na nadvládu nové šlechty nad dobytým územím (Lippmann 1998, 271-279). Raně novověkým bastionovým systémům je v návaznosti na kastelologii věnována pozornost zejména v zahraničí, kde vznikají studie k pevnostem v Německu, Polsku, Švédsku, Dánsku, Rusku, Pobaltí, Rakousku (Mitchell 2013, 365-378) aj. Dlouhodobě je věnována pozornost i francouzské fortifikační škole neodmyslitelně spjaté s dílem Sébastiena Le Prestre de Vauban, který žil v letech 1633 až 1707 (Le Blanc-Fauchere 2007). V Čechách a na Moravě lze nové fortifikační prvky (bastiony, toriony aj.) sledovat kolem vybraných hradů a zámků. Málokterý opevněný bod totiž vstupoval do války s moderním opevněním, jako tomu bylo v případě Doubravské Hory či Vítkova Kamene. Po konfiskacích a přerozdělení panství do rukou vítězných válečníků byly provedeny přestavby např́iklad na Bezdězu, v Brandýse nad Labem, v Náchodě, na Frýdlantu, Sovinci, Mírově, Hukvaldech, Helfštýně (Kupka 2006). V př́ípadě Frýdlantu jsou přestavby kladeny do souvislosti s pobytem švédských vojáků v tzv. „švédském dvoře u barbakánu“ v letech 1635 až 1649 (Tišerová-Stará 2007, 257). Jiné hrady byly naopak ničeny a zůstaly po válce pusté, což je např́iklad v západních Čechách případ Rýzmberku (Procházka 2004), Švamberku (Metlička-Orna-Zelenka 2008, 132-155; Kamenická 2009, 17-19), Třebele (Matoušek 2004), na Moravě pak případ hradu v Uherském Brodu (Opravil 1974, 220-225) ad. Nutno připomenout, že řada pevných míst měla být dle nařízení císaře Ferdinanda III. Habsburského z roku 1658 zbořena. U některých se tak stalo, jako např́iklad v případě Veliše, u jiných nikoliv, jako např́klad u Švihova. $Z$ hlediska archeologického je studium fortifikací ve vazbě na třicetiletou válku spíše sporadické. Výzkumy směřují zpravidla k poznání vývoje městských opevnění, jako např́íklad v Jihlavě (Černoš-Hejhal 2012, 389-402) či Chrudimi (Musil 2012, 365-388).

Výjimečným př́íkladem raně barokní rezidence je největší stavební podnik tohoto druhu v Čechách z doby třicetileté války, palácový komplex postavený v letech 1623 až 1629 pro generalissima císařské armády Albrechta z Valdštejna na Malé Straně v Praze, jemuž muselo ustoupit několik desítek městských domů. Mezi architektonicky náročné podniky patřilo také utváření komponované krajiny kolem rezidenčního města Jičína. $Z$ historicko-archeologického hlediska byly $\mathrm{v}$ této krajině zkoumány dochované stavby jako Valdštejnovo casino a relikty některých prvků (Uličný 2007, 239-244), pozornost byla věnována i jeho výbavě, zejména typologii umělecky hodnotných květináčů (Matějková 2012, 159-165). Obdobná studie pak vznikla i pro květináče z Valdic (Matějková-Svobodová 2017, 577-580). Podobně lze chápat i další raně barokní úpravy rezidencí nové šlechty na českém území. Příkladem může být vybudování zahrady s letohrádkem u zámku Lemberk Kryštofem Rudolfem Bredou, jenž byl synem kondotiéra Jana Rudofla Bredy. Ten přišel do Čech spolu s vojskem katolické ligy a jako Valdštejnův první důstojník obdržel zámek v severních Čechách, přičemž po smrti frýdlantského vévody v roce 1634 získal stavení do dědičného držení (Tišerová 2015, 94-111; 2017, 88-103). V této oblasti výzkumu se pozvolna začíná prosazovat také výzkum archeobotanický apod. (Bezděk a kol. 2016, 20-23).

\section{Válka a vybrané hospodářské aspekty}

Vojenské události výrazně přispěly k proměně hospodářství v českých zemích. Zatímco u některých řemesel došlo $\mathrm{k}$ recesi, jiná začala vzkvétat. $\mathrm{V}$ následující části bude pozornost 
věnována hrnčířství, kamnářství, sklářství, výrobě a zpracování kovů a zbrojnímu průmyslu. Jednotlivé lokality jsou vyznačeny opět na mapě č. 3 .

\subsection{Hrnčířství}

Mezi nejpočetnější nálezy při archeologických výzkumech tradičně patř́i keramické výrobky. Zájem je nejen o evidenci a dokumentaci jednotlivých výrobků, ale také je zkoumána produkce (např. Čapek-Preusz 2019), obchod a spotřeba výrobků (Preusz 2017). Důležitou zájmovou oblastí výzkumu je sledování zničených výrobních center.

$\mathrm{Na}$ Moravě jde o již zmíněná centra výroby novokřtěnců. Habánská hrnčířská výroba doznala největšího rozkvětu v letech 1580 až 1620. Za největší výrobní centra jsou považovány vsi Dambořice, Kobylí, Ostrožská Nová Ves, Podivín, Pouzdřany, Stará Břeclav, Strachotín, Šakvice, Tavíkovice, Trstěnice, Vacenovice a Žádovice, přičemž v písemných pramenech jsou zmiňovány ještě Alexovice, Ladná a Přibice (Pajer 2011, 3). Během třicetileté války byla jednotlivá sídla vystavována atakům ze strany protestantů i katolíků. Z náboženských důvodů byli novokřtěnci roku 1622 definitivně vyhnáni z jižní Moravy do horních Uher.

Druhým př́íkladem je zničení hrnčířských dílen na Horním, resp. Hrnčířském předměstí Berouna (srov. Vařeka 2003, 78-84; Vyšohlíd 2015, 411-430; Vyšohlíd-Zavřel 2016, 41-48). Význam zdejších dílen rostl od druhé poloviny 16. století, nebot' zde bylo produkováno tzv. „berounské zboží“. Výrobky byly charakteristické oranžovým střepem, jenž byl bohatě dekorován malovanými motivy v bílých, hnědých a zelených odstínech (Žegklitz 2015, 110-123). Šlo o zboží dekorované kukačkou, což byla výzdoba v renesančním období poměrně široce rozšířená a oblíbená (Endres 2005, 32, taf. 7.1) - toto zboží se prodávalo jak do měšt’anských domácností v Hořovicích (Koucký-Stolz-Stolzová 2004, 796), Praze (Charvátová-Charvát 1981, 333; Havrda-Matějková 2015, 128, 130, obr. 5; Huml 1971, 223; 1995, 23), Nymburku (Motyková 2003b, 772, 775, obr. 6:9, 6:10; Sedláčková-Brožková-Stará 1997, 28-30), Ústí nad Labem (Cvrková 2001, 267-279; Cvrková-Černá 2007, 79-80, obr. 2E:6, 2E:8), tak vrchnostenských sídel a vrchností zřizovaných provozoven. Dokladem jsou archeologické nálezy berounského zboží z Pražského hradu (Blažková-Dubská 2007) a císařské sklárny v Broumech (Žegklitz 2007, 163, obr. 27:6). Přribývají také nálezy keramiky ve vesnickém prostředí (Dudková-Orna-Vařeka 2008, 76-80). Zajímavým dokladem rezistence městských či venkovských hrnčírư postižených válkou je přesun výrobních zařízení z postižených sídel do alternativních útočišt'. Dokladem jsou nálezy hrnčířských pecí ve valech raně středověkého hradiště v Mikulčicích (Mazuch 2012, 7-45).

Fenoménem první poloviny 17. století je produkce a distribuce hliněných dýmek, nebot' kouření patřilo k oblíbeným zlozvykům mezi vojáky a rychle se šírilo i mezi civilisty (Ansorge 2007, 37-40; Mehler 2007, 28-32). Pro období třicetileté války jsou v Čechách a na Moravě typické jednodílné dýmky. Př́iklady pochází z Domažlic (Procházka 1983, 16-17, tab. 17, č. 11/3), Jičína (Ulrychová 2010, 929-932), Chrudimi (Musil 2008, 3-35), Modlibohova (Tišerová-Stará 2007, 258, 515, obr. 13.11.2), Třebele (Matoušek 2006, 144, obr. 38:5, obr. 38:6) či Záluží u Velešína (Preusz 2016, 400, 493, obr. 2:a).

\subsection{Kamnářství}

V rámci dlouhodobého výzkumu vytápěcích novověkých těles, kam patří zejména kachlová kamna či jednotlivé kachle jako základní konstrukční prvky, dochází k hodnocení jednotlivostí i rozsáhlejších souborů z období třicetileté války. Studium se zaobírá technologickým zpracováním surovin, výrobou matric a kachlů, deskripcí a ikonografickým rozborem výzdobných motivů. Mezi významnější nálezy lze zařadit relikty kamen ze sklárny v Broumech (Žegklitz-Hazlbauer-Chotěbor 1992, 94-108), z Prahy-Vysočan (Bureš 2002), z tvrze v Chotětíně (Frýda 2007, 37), ze zaniklé vsi Cetkov (Dudková-Orna-Vařeka 2008, 79-80), ze Sudoměřic u Bechyně (výzkum Husitského muzea v Táboře). Další soubory datované do první třetiny 17. století pochází např́íklad z Litovle (Hlubek-Šlézar 2016, 51-65) či Chořelic (Hlubek-Faltýnek 2016, 113-124). 
Patrně sem patří i nález pozdně renesančních kachlů v Dobrčicích na Přerovsku (Schenck-Mikulík 2014, 15-16). Reprezentativní kolekce portrétních kachlů pochází z Ústí nad Labem. Na kachlích jsou zde vyobrazeni císař Rudolf II. Habsburský (1552-1612), saský kurfiřt Jan Jiří I. z rodu Wettinů (1611-1656), král Kristián IV. Dánský (1577-1648) ad. (srov. Šrejberová 2018). Portrétní kachel císaře Ferdinanda II. Štýrského (1578-1637) pochází z Opavy (MenouškováMěřínský 2008, 82, obr. 240). Vedle portrétních kachlů se objevují také kachle žánrové, antikizující a ornamentální. Mimo vysoce reprezentativní kachle se však uplatňovaly také kachle strohé, pro něž byla př́źznačná aplikace jednoduchého architektonického či geometrického motivu (Pavlík-Vitanovský 2004, 21-26). Kachle tohoto typu patřily např́íklad k charakteristickým produktům novokřrtěnských kamnářů. Odvrhnutý výzdobný aparát je však typický i pro běžného spotřebitele ve válečných letech, příkladem mohou být medailonovité kachle z několikrát připomínané zaniklé vsi Cetkov či na téže lokalitě nalezené nádobkové kachle (Dudková-Orna-Vařeka 2008, 79-80).

\subsection{Sklářství}

Specifikou české archeologie je dlouhodobý zájem o výzkum středověkých a raně novověkých skláren, zejména v pohraničních horských a lesnatých oblastech. Nutno podotknout, že sklárny produkující renesanční sklo se začínají objevovat před polovinou 16. století a od druhé poloviny téhož století došlo k enormnímu nárůstu jejich počtu (Sedláčková 2003, 47-67). Nejstarší sklárny byly tvořeny zpravidla nevelkou tavicí pecí, která byla chráněná dřevěným přístřeškem. Stanoviště skláren nebylo stálé a měnilo se vždy, když v okolním lese docházelo dříví. K výrobnímu sortimentu nejstarších skláren patřily okenní terčíky, duté sklo a páteříky. V rámci studia třicetileté války lze za klíčový považovat archeologický výzkum císařské sklárny v Broumech v křivoklátských lesích, která definitivně zanikla v důsledku švédského vpádu do Čech roku 1639 (Žegklitz 2007, 145-180; 2007a, 118-126). Na Zbirožsku proběhla lokace sklárny ve Skelné Huti (Brejcha 2013, 211-212). Další zaniklé sklárny jsou evidovány např́iklad v Českém lese, lze zmínit sklárny Mostek, Stará Hut', Draxelhütte, Rozvadov (Procházka 2009, 13, 152-154, 177-178, 256-258).

Informace z produkčního prostředí pak lze doplnit o nálezy ze sféry spotřební. Mimo tradiční šlechtickou, církevní či městskou konzumní sféru začínají přibývat také nálezy skla ve vesnickém prostředí (např. Cvrková-Černá 2007, 77-90; Frýda 2007, 33-65). Nálezy zlomků okenních terčíků a dutého skla svědčí o tom, že sklo bylo na trhu dostupné nejširším sociálním vrstvám.

\subsection{Výroba a zpracování kovi̊}

Historicko-archeologický výzkum železářství je tradičně rozvíjen zejména ve Švédsku, které na hutnictví železa postavilo svou válečnou a poválečnou ekonomiku (Af Geijerstam-Nisser 2011, 54-91). Pomocí archeologických metod jsou dokumentovány doly, hutě, hamry, vysoké pece, výrobny děl a zbraní. Zničený železný hamr byl detekován v blízkosti města Zhořelce (Görlitz) v roce 2017. V sutinách byla povrchovým sběrem získána bohatá kolekce reliéfně zdobených komorových kachlů, kamenin, keramiky, dýmek a dalších artefaktů (výzkum Vratislavské univerzity a ZČU v Plzni v roce 2017).

V České republice se hutnictví a zpracování kovů rozvíjelo od počátku 16. století zejména kolem Kutné Hory a na Plzeňsku, významnou se stala také Valdštejnova Raspenava (Hofmann 1964). Ve válečném období bylo pro výrobu střelného prachu dủležité disponovat značným množstvím sanytru, síry a dřevěného uhlí. Nejstarší provozy zaměřené na těžbu a zpracování pyritických nerostných surovin se nacházely u Chomle a v Darové u města Radnice na Rokycansku. Během války se stávaly tyto strategické provozy cílem útoků. Reliktům těchto provozů, kde 
se vyráběla kyselina sírová, věnovali na Rokycansku v posledních letech pozornost především M. Lang a P. Rožmberský (Lang 2011, 44-47; Rožmberský-Chmelír 2015, 54-64).

$\mathrm{Z}$ hlediska válečného průmyslu v první polovině 17. století hraje klíčovou roli výzkum železářského regionu kolem Strašic a Dobřrivi, kde byly po roce 1600 vybudovány vysoké pece a železářské hamry na výrobu munice, děl, zbraní, zbrojí aj. (kontext např. Hofmann 1968; Rožmberský 2010, 43-67). V okolí Strašic byla učiněna prospekce středověkých těžebních areálů a výrobních provozoven, na jejichž produkci novověká výroba navázala. Lokalizována byla těžba železné rudy, milíriššě, relikty hamrů atd. (Nováček 2007, 164-172). Další krajinný transekt byl zkoumán například v okolí Lhoty pod Radčem, kde byly sledovány milíře pro výrobu dřevěného uhlí k pohánění železářských pecí (Brejcha 2013, 200-220).

Do procesu získávání železné rudy byly zapojeny také specializované úpravny železné rudy. Archeologický výzkum výrobny byl proveden ve Všeni u Turnova v oblasti Českého ráje. V této oblasti byly těženy železivce v podobě subvertikálních a subhorizontálních desek. Úprava rudy probíhala drcením a propíráním, při němž byly odstraňovány přebytečné křemičité sloučeniny. Základem provozu byl roubený trojdílný dům s chlévem v zadním traktu, hnojištěm, špýcharem a dalšími objekty. Pro úpravu rudy zde byl vybudován vodní kanál s nádrží, kamenné mlaty a pec (Prostředník-Š́da 2009, 147-158).

\subsection{Zbrojní průmysl}

Téma vojenské výstroje, výzbroje a zbraní tvoří důležitou část výzkumu třicetileté války. Cílem je ve spolupráci s vojenskými historiky poznat typologickou škálu a technologickou úroveň soudobých militarií. Zdrojem důležitých informací jsou nejen artefakty vyzvednuté prrímo v terénu, nejčastěji v produkčních centrech a na bojištích, ale i kolekce zbraní uchovávané v muzejních a zámeckých sbírkových fondech. Nejdůležitější kolekce lze nalézt ve velkých zbrojnicích v Drážd’anech, Kodani, Stockholmu, Praze, Plzni (Frýda 1988), Štýrském Hradci (Brooker 2007; Krenn 2000) Vídni i na zámcích, jakou jsou např́íklad Hluboká nad Vltavou, Opočno nebo Skokloster, jenž patřil polnímu maršálovi Carlu Gustavu Wrangelovi.

V posledních letech se začíná přikládat výrazně větší význam výzkumu střelného prachu, který je v současnosti považován za klíčový element, který rozhodoval jednotlivé bitvy (DeVries 1998, 127-145; Green 2004). Zajímavostí je, že k objevu střelného prachu z roku 1621 došlo v nevybuchlém granátu na bojišti u Rozvadova, výplň byla podrobena chemické analýze. Izotopové analýzy olova a měření kalibrů olověných či kompozitních střel pomáhají v posledních letech rozlišovat projektily jednotlivých vojsk na britských (Foard 2012, 41-120), německých (Engerisser, P. 2007) a nizozemských bojištích (Huisman et al. 2012). Samostatně se rozvíjí výzkum dělostřelectva, přičemž vedle výzkumu produkčních center děl zejména ve Švédsku (Hildebrand 1992, 25-42) probíhá alternativní historicko-archeologické studium výroben ve Strašicích a Dobřívi, kde se dochoval železný hamr. Experimentální výroba děla a střelba různými typy projektilů byla provedena $\mathrm{v}$ kontextu výzkumu švédské vlajkové lodi Vasa, která se potopila krátce po vyplutí z př́ístavu ve Stockholmu v roce 1628. Její vylovení z moře bylo dosud největším počinem podmořské archeologie v oblasti Baltského moře. Dnes je lod' umístěna v muzeu Vasa ve Stockholmu, kde je z nejrůznějších úhlů pohledu systematicky studována (Cederlund-Hocker 2006; Hocker 2011) a funguje jako významná laboratoř pro konzervaci organických materiálů, zejména dřeva (Cabrera Tejedor 2010). Zajímavostí je, že v současnosti patří muzeum mezi nejnavštěvovanější archeologická muzea zaměřená na vojenskou tematiku na světě, návštěvnost přesahuje 1300000 návštěvníků za rok (Sutherland 2005, 7). Postupně se množí solitérní nálezy, které jsou samostatně publikovány. Jde o střelné zbraně a jejich příslušenství (Ludwig-Cüppers 2005, 1-2; Musil 2015, 94-105), bomby a granáty (Schußmann 2014, 34-37), meče (Žákovský-Drnovský 2017, 279-295), zbroje (Höft 1998), vojenské doplňky (Musil 2010, 181-190). Pozornost lze věnovat také militariím z moravských sbírek (Žákovský 2011, 105-159) a archeologických lokalit, např́íklad z Horních Moštěnic či Helfštýna (Žákovský-Schenk 2017). 


\section{Depoty a poklady $z$ třicetileté války}

Není cílem tohoto článku podat vyčerpávající přehled depotů z třicetileté války ve střední Evropě ani u nás. Jen na území ČR lze odhadovat, že jde o více než 350 př́ikladů (obr. 4). Přitom množství depotů uniká pozornosti badatelů, nebot’ se stává kořistí ilegálních hledačů pokladů. V následující stati upozorňuji na fenomén depotu jako celku a představuji reprezentativní lokální studie, které mohou být vodítkem pro další nálezce a badatele.

Pojem depot nezahrnuje pouze soubory mincí, nýbrž jakékoliv předměty záměrně uschované v otevřené krajině i uvnitř lidských sídel. Depoty a poklady z válečných let, s nimiž se archeologie nejčastěji setkává, jsou tvořeny zpravidla cennostmi. Nejčastěji jde o keramickou nebo cínovou nádobu či dřevěnou schránku, do níž byl vložen váček s mincemi. To pak doplňují nálezy kovového nádobí, prstenů, medailí, perel, zlatých pásů a řetízků s bizamovými jablky, která se s oblibou používala jako voňavý kosmetický doplněk. Někdy se lze setkat s depotem řemeslnických nástrojů, které byly klíčové pro zajištění živobytí. V depotech, které zakopávali žoldnéři, se objevují také zbraně a munice.

Naši pozornost si zaslouží také depoty nádobí. V blízkosti města Gützkow (Meklenbursko-Přední Pomořansko) bylo objeveno sedm kovových nádob, které byly původně schovány do břehu mlýnského rybníku, který se zde nacházel. O jeho existenci svědčí švédská mapa z roku 1694. Nádoby, které se kolem roku 1627 staly válečnou kořistí, tvoří dva 60litrové kotle se železnými uchy, dva trojnohé kotlíky typu grapen z bronzu s větší příměsí cínu a tři mosazné hluboké mísy s uchy (Schirren 2015, 439-440). U Behren-Lübchin (Meklenbursko-Přední Pomořansko) byly v břehu dnes již vysušeného jezera objeveny dva měděné kotle naplněné více než 40 cínovými taliřri a miskami (Kruse 1996, 169-182). Cenné kolekce nádobí z dánsko-švédských válek kolem poloviny 17. století jsou k vidění v Národním muzeu v Kodani (Grinder-Hansen 2002). V Čechách byly kolekce nádobí nalezeny např́iklad v Sušici. V roce 1930 byl v domě čp. 34/I nalezen v úkrytu soubor cínového nádobí sušické zámožné měštanské domácnosti z druhé poloviny 16. a počátku 17. století, který patrně schoval sušický primátor Adam Čech před svým odchodem do exilu po bitvě na Bílé hoře. Stolní nádobí bylo vystaveno na kredenci a soubor čítal 86 kusů, šlo o 32 velkých mis, šest misek, 27 talířu (plochých, mírně hlubokých, hlubokých na nožičkách, dedikačních), jedenáct menších konvic, tři velké konve, dvě čtyřhranné láhve na olej, dvě slánky, tři svícny, jedno lavabo a jednu zásuvku patrně z kredence. Všechno nádobí je označeno znamením majitele, a to bud' v podobě monogramů nebo ve spojení s rodovým znamením. Cínové nádobí pochází z dílen v Sušici (64ks), Norimberku (18ks), Jindřichova Hradce (8 ks) a po jednom kusu z Prahy, Plzně, Kutné Hory, Slavkova a Horažd’ovic (Petráň 1995, 488). K dalšímu nálezu cínových holeb došlo např́íklad u Hut'ského Dvora na Šumavě (Beneš 1991, 129-135). Problematická je datace kolekce stř́ibrného nádobí z Týna nad Vltavou, u něhož není zcela zřejmé, zda jde o depot související s počátkem třicetileté války či jinými událostmi, např́íklad vpádem Pasovských (Novotná 2013).

Nejpočetnější skupinu depotů tvoří soubory mincí, které jsou nalézány ve všech evropských zemích, které válka zastihla (např. Ilisch 1998; 2002). Mincím z období třicetileté války byla tradičně věnována pozornost z numismatického úhlu pohledu. Zkoumán je jejich původ, nominální hodnota aj. (Kostlán 1986, 191-236). Pozvolna začaly být mincím kladeny nové otázky z archeologického úhlu pohledu, jako v př́ípadě depotu z Trhových Svinů (Militký 1996, 239-245; 1997, 107-132, 170-172) nebo Všerubského průsmyku (Břicháček-Metlička-Pavlík 2016, 193-200). Teprve v posledních letech se dočkaly některé nálezy monografického zpracování, a to poklad z jihočeského Bošilce (Chvojka-John-Thomová 2016), Týna nad Vltavou (John-Kolář 2017), jihomoravských Boskovic (Grossmannová 2014) a severočeského Frýdlantu (Tišerová 2018). V knihách se snoubí analýzy různých vědních oborů, zvláště numismatiky, archeologie, environmentální archeologie, historie a chemie. Pozornost je vedle numismatického rozboru věnována nálezové situaci, př́rodnímu i sociálnímu kontextu nálezu.

Samostatnou skupinou artefaktů, jimž historie a archeologie věnuje pozornost, jsou kolekce cenností a kuriozit, jež byly odvezeny švédskými vojsky do Skandinávie. Zejména jde 


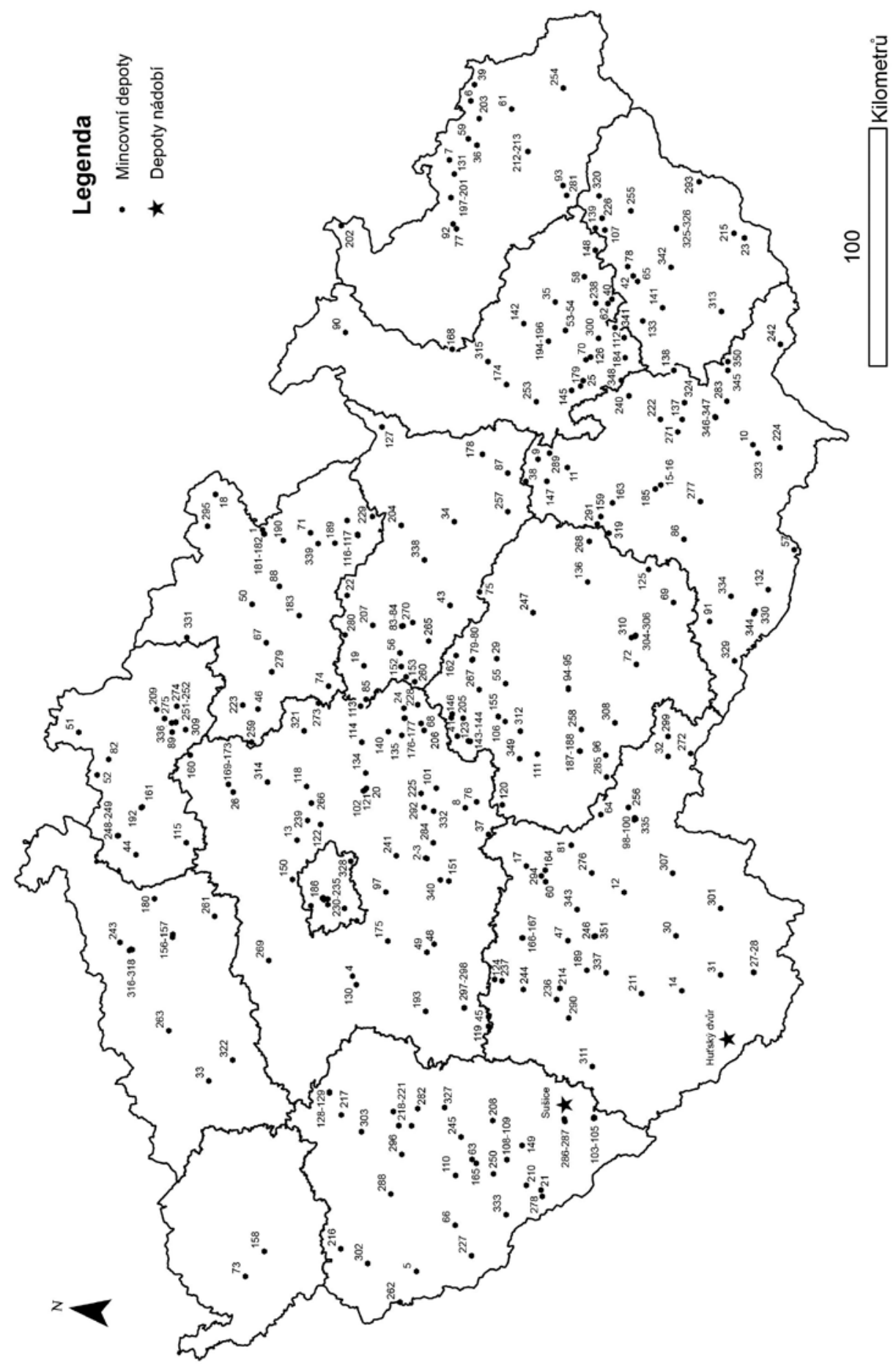


Mapa 4. Lokality s nálezy mincovních depotů z doby třicetileté války: 1 - Běloves; 2-3 - Benešov 1-2; 4- Beroun; 5 - Bezděkov; 6 - Bohumín; 7 - Bolatice; 8 - Bolina; 9 - Borotín; 10 - Bořetice; 11 - Boskovice; 12 - Bošilec; 13 - Brandýs n. Labem; 14 - Brloh; 15-16 - Brno 1-2; 17 - Broučkova Lhota; 18 - Broumov; 19 - Břehy 1-3; 20 - Bukačov; 21 - Býškovice; 22 - Býšt' u Holic; 23 - Bzová; 24 - Čáslav; 25 - Čechovice; 26 - Čejetice; 27-28 - Čeřín 1-2; 29 - Česká Bělá; 30 - České Budějovice; 31 - Český Krumlov; 32 - Český Rudolec; 33 - Čínov; 34 - Čistá; 35 - Daskabát; 36 - Děhylov; 37 - Děšenice; 38 - Deštná; 39 - Dětmarovice; 40 - Dobrčice; 41 - Dobrnice; 42 - Dobrotice; 43 - Dolní Holetín; 44 - Dolní Libchava; 45 Drahenice; 46 - Drahoraz; 47 - Dražíč; 48 - Drevníky u Dobříše; 49 - Drhovy; 50 - Dvůr Králové nad Labem; 51 - Frýdlant; 52 - Grabštejn; 53 - Grygov 1; 54 - Grygov 2; 55 - Havlíčkủv Brod; 56 - Heřmanủv Městec; 57 - Hevlín; 58 - Hlinsko; 59 - Hlučín; 60 - Horky; 61 - Horní Datyně; 62 - Horní Moštěnice; 63 - Horní Ostrovec; 64 - Horní Radouň; 65 - Horní Újezd; 66 - Horšovský Týn; 67 - Hořice; 68 - Hraběšín; 69 - Hrotovice; 70 - Hrubčice; 71 - Chábory; 72 - Chlístov; 73 Chlum sv. Mař́i 74 - Chlumec nad Cidlinu; 75 - Chlumětín; 76 - Chmelná; 77 - Choltice; 78 - Chomýž; 79 - Chotěboř 1 ; 80 - Chotěboř 2; 81 - Choustník; 82 - Chrastava; 83 - Chrudim 1; 84 - Chrudim 2; 85 - Chvaletice; 86 - Ivančice; 87 - Janůvky; 88 - Jaroměř; 91 - Jenišovice; 90 - Jeseník; 91 - Jevišovice; 92 - Jezdkovice; 93 - Jičina; 94 - Jihlava 1; 95 - Jihlava 2; 96 - Jihlávka; 97 - Jílové u Prahy; 98-100 - Jindřichův Hradec 1-3; 101 - Kácov; 102 - Kamberk; 103-105- Kašperské Hory 1-3; 106 - Kejžlice; 107 - Kelč; 108-109 - Klatovy 1-2; 110 - Kloušov; 111 - Kojčice; 112 - Kojetín; 113 - Kojice; 114 - Kolín; 115 - Korce; 116-117 - Kostelec n. Orlicí 1-2; 118 - Kostomlaty nad Labem; 119 - Koupě; 120 -121 - Kouřim 1-2; 122 - Kovovazy; 123 - Kozlov; 124 - Kožlí; 125 - Kralice; 126 - Kralice na Hané; 127 - Králíky; 128-129 - Kralovice; 130 - Králův Dvůr; 131 - Kravaře; 132 - Krhovice; 133 - Kroměříž; 134 - Krychnov; 135 - Křesetice; 136 - Křižanov; 137 Křižanovice; 138 - Kunkovice; 139 - Kunovice; 140 - Kutná Hora; 141 - Kvasice; 142 - Lašt’any; 143 -144 - Ledeč n. Sázavou 1-2; 145 - Lešany; 146 - Leština; 147 - Letovice; 148 - Lhovice u Švihova; 149 - Lhůta; 150 - Líbeznice; 151 - Libohošt'; 152 - Licomělice; 153 - Licoměřice; 154-155 - Lipnice nad Sázavou 1-2; 156-157 - Litoměřice 1-2; 158 - Litrbach; 159 Lomnička; 160 - Loukov; 161 - Lukavec; 162 - Maleč; 163 - Malhostovice; 164 - Měšice; 165 - Mezihoří; 166-167 - Milevsko 1-2; 168 - Mirotínek; 169-173 - Mladá Boleslav 1-5; 174 - Mladeč; 175 - Mníšek; 176-177 - Močovice 1-2; 178 - Moravská Třebová; 179 - Mostkovice; 180 - Muckov; 181-182 - Náchod 1-2; 183 - Neděliště; 184 - Němčice nad Hanou; $185-186$ neznámé naleziště 1-2; 187-188 - Nová Buková 1-2; 189 - Nová Ves; 190 - Nové Město nad Metují; $191-192$ - Noviny p. Ralskem 1-2; 193 - Obecnice; 194-196 - Olomouc 1-3; 197-201 - Opava 1-5; 202 - Osoblaha; 203 - Ostrava; 204 - Oucmanice; 205 - Ovesná Lhota; 206 - Paběnice; 207 - Pardubice; 208 - Partoltice; 209 - Pěnčín; 210 - Petrovice n. Úhlavou; 211 - Petrův Dvůr; 212-213 - Petřvaldík 1-2; 214 - Písek; 215 - Pitín; 216 - Planá u M. Lázní; 217 - Plasy; $218-221$ - Plzen̆ 1-4; 222 - Podbřežice; 223 - Podhradí; 224 - Podivín; 225 - Podveky; 226 - Police; 227 - Postřekov; 228 - Potěhy; 229 Potštejn; 230-235 - Praha; 236 - Prácheňsko; 237 - Probulov; 238 - Přerov; 239 - Přerov nad Labem; 240 - Pustiměř; 241 - Pyšely; 242 - Radějov; 243 - Radešín; 244 - Radešov u Volyně; 245 - Radkovice; 246 - Radonice; 247 - Radonín; 248-249 - Radvanec 1-2; 250 - Řakom; 251-252 - Rakousy; 253 - Raková u Konice; 254 - Raškovice; 255 - Ratiboř; 256 - Rodvínov; 257-258 - Rohozná 1-2; 259 - Rokytňany; 260 - Ronov nad Doubravou; 261 - Roudnice n. Labem; 262 Rozvadov (ztrátová mince); 263 - Rudolice; 264 - Rychnov nad Kněžnou; 265 - Samařov; 266 - Semice; 267 - Skruhrov; 268 - Skryje; 269 - Slaný; 270 - Slatiňany; 271 - Slavkov u Brna; 272 - Slavonice; 273 - Slibovice; 274 - Smrčí; 275 - Sněhov; 276 - Soběslav; 277 - Sobotovice; 278 - Stará Lhota; 279 - Staré Smrkovice; 280 - Staré Ždánice; 281 - Starý Jičín; 282 Starý Plzenec; 283 - Strážovice; 284 - Struhařov; 285 - Sudoměřice u Bechyně; 286-287 - Sušice 1-2; 288 - Sytno; 289 - Šebetov; 290 - Štěkeň; 291 - Štěpánovice; 292 - Šternberk; 293 - Študlov; 294 - Tábor; 295 - Teplice nad Metují; 296 - Tlučná; 297-298 - Tochovice 1-2; 299 - Toužín; 300 - Tovačov; 301 - Trhové Sviny; 302-303 - Trnová 1-2; 304-306 - Třebíč 1-3; 307 - Třeboň; 308 - Třeštice; 309 - Turnov; 310 - Týn; 311 - Týn nad Vltavou; 312 - u Humpolce; 313 - Uherské Hradiště; 314 - Újezd; 315 - Uničov; 316-318 - Ústí nad Labem; 319 - Úsuší; 320 - Valašské Meziříčí; 321 - Velenice; 322 - Veletice; 323 - Velké Pavlovice; 324 - Vicemilice; 325-326 - Vizovice 1-2; 327 - Vlčtejn; 328 - Vodice; 329 - Vranov; 330 - Vranová; 331 - Vrchlabí; 332 - Všechlapy; 333 - Všeruby; 334 - Výrovice; 335 - Vyšpachy; 336 - Záborčí u Turnova; 337 - Záboří; 338-339 - Zádolí 1-2; 340 - Zahrádka; 341 - Záříčí; 342 - Zlín; 343-344 - Znojmo 1-2; 345 - Žádovice; 346 -347 - Žarošice 1-2; 348 - Želeč; 349 - Želiv; 350 - Žeravice; 351 - Žirovnice. ㄷ M. Preusz.

Karte 4. Fundstellen mit Münzhortfunden aus der Zeit des Dreißigjährigen Krieges: 1 - Běloves; 2-3 - Benešov 1-2; 4 Beroun; 5 - Bezděkov; 6 - Bohumín; 7 - Bolatice; 8 - Bolina; 9 - Borotín; 10 - Bořetice; 11 - Boskovice; 12 - Bošilec; 13 - Brandýs n. Labem; 14 - Brloh; 15-16 - Brno 1-2; 17 - Broučkova Lhota; 18 - Broumov; 19 - Břehy 1-3; 20 - Bukačov; 21 - Býškovice; 22 - Býšt' u Holic; 23 - Bzová; 24 - Čáslav; 25 - Čechovice; 26 - Čejetice; 27-28 - Čeřín 1-2; 29 - Česká Bělá; 30 - České Budějovice; 31 - Český Krumlov; 32 - Český Rudolec; 33 - Číñov; 34 - Čistá; 35 - Daskabát; 36 - Děhylov; 37 - Děšenice; 38 - Deštná; 39 - Dětmarovice; 40 - Dobrěice; 41 - Dobrnice; 42 - Dobrotice; 43 - Dolní Holetín; 44 - Dolní Libchava; 45 - Drahenice; 46 - Drahoraz; 47 - Dražíč; 48 - Drevníky u Dobř́iše; 49 - Drhovy; 50 - Dvůr Králové nad Labem; 51 - Frýdlant; 52 - Grabštejn; 53 - Grygov 1; 54 - Grygov 2; 55 - Havlíčkův Brod; 56 - Heřmanův Městec; 57 Hevlín; 58 - Hlinsko; 59 - Hlučín; 60 - Horky; 61 - Horní Datyně; 62 - Horní Moštěnice; 63 - Horní Ostrovec; 64 - Horní Radouň; 65 - Horní Újezd; 66 - Horšovský Týn; 67 - Hořice; 68 - Hraběšín; 69 - Hrotovice; 70 - Hrubčice; 71 - Chábory; 72 - Chlístov; 73 - Chlum sv. Maří; 74 - Chlumec nad Cidlinu; 75 - Chlumětín; 76 - Chmelná; 77 - Choltice; 78 - Chomýž; 79 - Chotěboř 1; 80 - Chotěboř 2; 81 - Choustník; 82 - Chrastava; 83 - Chrudim 1; 84 - Chrudim 2; 85 - Chvaletice; 86 - Ivančice; 87 - Janůvky; 88 - Jaroměř; 91 - Jenišovice; 90 - Jeseník; 91 - Jevišovice; 92 - Jezdkovice; 93 - Jičina; 94 Jihlava 1; 95 - Jihlava 2; 96 - Jihlávka; 97 - Jílové u Prahy; 98-100 - Jindřichův Hradec 1-3; 101 - Kácov; 102 - Kamberk; 103-105 - Kašperské Hory 1-3; 106 - Kejžlice; 107 - Kelč; 108-109 - Klatovy 1-2; 110 - Kloušov; 111 - Kojčice; 112 - Kojetín; 113 - Kojice; 114 - Kolín; 115 - Korce; 116-117 - Kostelec n. Orlicí 1-2; 118 - Kostomlaty nad Labem; 119 - Koupě; 120-121 - Kouřim 1-2; 122 - Kovovazy; 123 - Kozlov; 124 - Kožlí; 125 - Kralice; 126 - Kralice na Hané; 127 - Králíky; 128-129 - Kralovice; 130 - Králův Dvůr; 131 - Kravaře; 132 - Krhovice; 133 - Kroměříž; 134 - Krychnov; 135 - Křesetice; 136 - Křižanov; 137 - Křižanovice; 138 - Kunkovice; 139 - Kunovice; 140 - Kutná Hora; 141 - Kvasice; 142 - Lašt’any; 143-144 - Ledeč n. Sázavou 1-2; 145 - Lešany; 146 - Leština; 147 - Letovice; 148 - Lhovice u Švihova; 149 - Lhůta; 150 Líbeznice; 151 - Libohošt'; 152 - Licomělice; 153 - Licoměřice; 154-155 - Lipnice nad Sázavou 1-2; 156-157 - Litoměřice 1-2; 158 - Litrbach; 159 - Lomnička; 160 - Loukov; 161 - Lukavec; 162 - Maleč; 163 - Malhostovice; 164 - Měšice; 165 Mezihoří; 166-167 - Milevsko 1-2; 168 - Mirotínek; 169-173 - Mladá Boleslav 1-5; 174 - Mladeč; 175 - Mníšek; $176-177$ Močovice 1-2; 178 - Moravská Třebová; 179 - Mostkovice; 180 - Muckov; 181-182 - Náchod 1-2; 183 - Neděliště; 184 Němčice nad Hanou; 185-186 - neznámé naleziště 1-2; 187-188 - Nová Buková 1-2; 189 - Nová Ves; 190 - Nové Město nad Metují; 191-192 - Noviny p. Ralskem 1-2; 193 - Obecnice; 194-196 - Olomouc 1-3; 197-201 - Opava 1-5; 202 - Osoblaha; 203 - Ostrava; 204 - Oucmanice; 205 - Ovesná Lhota; 206 - Paběnice; 207 - Pardubice; 208 - Partoltice; 209 - Pěnčín; 
210 - Petrovice n. Úhlavou; 211 - Petrův Dvůr; 212-213 - Petřvaldík 1-2; 214 - Písek; 215 - Pitín; 216 - Planá u M. Lázní; 217 - Plasy; 218-221 - Plzeň 1-4; 222 - Podbřežice; 223 - Podhradí; 224 - Podivín; 225 - Podveky; 226 - Police; 227 - Postř̌ekov; 228 - Potěhy; 229 - Potštejn; 230-235 - Praha; 236 - Prácheňsko; 237 - Probulov; 238 - Přerov; 239 - Přerov nad Labem; 240 - Pustiměř; 241 - Pyšely; 242 - Radějov; 243 - Radešín; 244 - Radešov u Volyně; 245 - Radkovice; 246 - Radonice; 247 - Radonín; 248-249 - Radvanec 1-2; 250 - Řakom; 251-252 - Rakousy; 253 - Raková u Konice; 254 - Raškovice; 255 - Ratiboř; 256 - Rodvínov; 257-258 - Rohozná 1-2; 259 - Rokytňany; 260 - Ronov nad Doubravou; 261 - Roudnice n. Labem; 262 - Rozvadov (ztrátová mince); 263 - Rudolice; 264 - Rychnov nad Kněžnou; 265 - Samařov; 266 - Semice; 267 - Skruhrov; 268 - Skryje; 269 - Slaný; 270 - Slatiňany; 271 - Slavkov u Brna; 272 - Slavonice; 273 - Slibovice; 274 Smrěí; 275 - Sněhov; 276 - Soběslav; 277 - Sobotovice; 278 - Stará Lhota; 279 - Staré Smrkovice; 280 - Staré Ždánice; 281 - Starý Jičín; 282 - Starý Plzenec; 283 - Strážovice; 284 - Struhařov; 285 - Sudoměřice u Bechyně; 286-287 - Sušice 1-2; 288 - Sytno; 289 - Šebetov; 290 - Štěkeň; 291 - Štěpánovice; 292 - Šternberk; 293 - Študlov; 294 - Tábor; 295 - Teplice nad Metují; 296 - Tlučná; 297-298 - Tochovice 1-2; 299 - Toužín; 300 - Tovačov; 301 - Trhové Sviny; 302-303 - Trnová 1-2; 304-306 - Třebíč 1-3; 307 - Třeboň; 308 - Třeštice; 309 - Turnov; 310 - Týn; 311 - Týn nad Vltavou; 312 - u Humpolce; 313 - Uherské Hradiště; 314 - Újezd; 315 - Uničov; 316-318 - Ústí nad Labem; 319 - Úsuší; 320 - Valašské Meziříčí; 321 - Velenice; 322 - Veletice; 323 - Velké Pavlovice; 324 - Vicemilice; 325-326 - Vizovice 1-2; 327 - Vlětejn; 328 - Vodice; 329 - Vranov; 330 - Vranová; 331 - Vrchlabí; 332 - Všechlapy; 333 - Všeruby; 334 - Výrovice; 335 - Vyšpachy; 336 - Záborčí u Turnova; 337 - Záboří; 338-339 - Zádolí 1-2; 340 - Zahrádka; 341 - Záŕíćí; 342 - Zlín; 343-344 - Znojmo 1-2; 345 - Žádovice; 346-347 - Žarošice 1-2; 348 - Želeč; 349 - Želiv; 350 - Žeravice; 351 - Žirovnice. ㅇ M. Preusz.

o předměty z kunstkomory Rudolfa II. (Bauer-Haupt 1976, 1-143; Janáček 2003, 184-200; Morávek 1937), jež putovaly na př́ikaz královny Kristýny Švédské z Prahy do Stockholmu v roce 1648 (Englund 2008). Patří mezi ně například Codex Argenteus (Kleberg 1984) nebo Codex Gigas (Bártl-Kostelecký 1993). Další cennosti se nachází v soukromých sbírkách válečných podnikatelů, jako např́iklad Carla Gustava Wrangela ve Skoklosteru - kolekce vzácného nádobí, portrét Rudolfa II. v podobě Vertumna (Bengtsson 1995). Základním vodítkem, v němž se nachází analýza původu švédských historických fondů z hlediska válečných zisků Švédska v 17. století, je kniha švédského historika Otto Waldeho (Walde 2016-2020). Výstavní a konferenční aktivity švédského vojenského muzea v letech 2006-2008³ zvýšily zájem o systematické shromažd’ování a zpř́istupňování ukořistěných českých a moravských knihoven, které putovaly nejprve do Švédska a postupně se jejich části rozšiřily do nejrůznějších zákoutí Evropy. Odhaduje se, že šlo o celkem 20000 titulů (např. Karlsson 1998; 1998a; 2000; Veselá 2005; 2013; 2014).

\section{Shrnutí}

Podaný přehled o stavu a rozvoji historicko-archeologického výzkumu třicetileté války zejména od 90 . let 20. století naznačuje, že je v Evropě dostatek zájmových objektů, tematických okruhů a památek, které si v blízké budoucnosti zaslouží větší pozornost. Historická archeologie třicetileté války vyrůstá z nesystematických menších, zpravidla úzce lokálních výzkumů, přičemž po otevření hranic $\mathrm{v}$ roce 1989 a se zaváděním moderních metod, např́íklad geografických informačních systémů, dostává zcela nový prostorový rámec, v němž lze využít lokální výzkumy ke studiu globálních jevů, které se netýkají pouze lidí známých z písemných pramenů, ale i anonymních účastníků války (např. měštané, vesničané, vojáci). Interdisciplinární výzkum může totiž měřit kulturní úrovně a konfesní založení domácností, studovat válečnou populaci, jejich stravu, nemoci, zranění, techniky zabíjení, systematiku plundrování a ničení, rezistenci prohrávajících a dominanci vítězů, restrukturalizaci výroby, trhů a spotřeby aj. Zároveň je nutné věnovat pozornost environmentálním aspektům, které měly vliv na sociální a kulturní změny během válečných let. Jde o studium klimatických změn skrze dendrochronologické a palynologické výzkumy, díky nimž lze exaktně potvrdit nejen výrazný pokles teplot a zvyšování vlhkosti, ale i kolísání klimatu v rámci studeného inter-sekulárního období na počátku 17. století (Büntgen et al. 2011). S narušením patternu renesanční krajiny během války souvisí sledování biodiverzity, kdy dochází k regresi zemědělské krajiny (např. změna obilnářství), progresi železářství (např. úbytek tvrdého dříví) a proměně lesů (např. zvětšování teritorií divokých vlků;

3 Šlo o akce Grönhmmar, A. (ed.), 2007: Krigsbyte = War-booty. Stockholm, Livrustkammaren; Nestor, S., 2009: War-booty: a common European cultural heritage: an international symposium at the Royal Armoury 29-31 May 2008. Stockholm, Livrustkammaren. 
Poschold 2015, 102). V zorném úhlu by měla být také ekosystémová otázka využívání energií a zdrojů, např́ílad nerostných surovin, v 16. a 17. století (Majer 2004).

V žádné evropské zemi dosud nebyla komplexně daná tematika studována, v žádné zemi např́íklad nemáme k dispozici seznam jasně definovaných areálů bojišt' z třicetileté války (jediným komplexně zkoumaným bojištěm je doposud Lützen). Předložená studie nastínila současný stav jednotlivých témat $\mathrm{v}$ evropských zemích $\mathrm{s}$ akcentem na výzkum v Čechách, na Moravě a ve Slezsku. Hlavní perspektivou dalšího výzkumu je komplexní zkvalitnění archeologického výzkumu bojišt' v ČR, přičemž by měla být zvýšena ochrana jednotlivých areálů před ilegálním vykrádáním. Cílem bádání by mělo být komplexní studium sídelních a hospodářských struktur na větších územních celcích. K tomu může přispět pouze zkvalitnění spolupráce historiků, archeologů, historiků umění, antropologů, krajinných ekologů a dalších specialistů. Obrovský potenciál v sobě zahrnuje formování mezinárodních výzkumných týmů, které mohou vzájemně porovnávat dopady a př́inosy války v různých zemích.

\section{Závěr}

$\mathrm{Z}$ přehledu současného stavu výzkumu třicetileté války $\mathrm{z}$ archeologického úhlu pohledu jasně vyplývá, že téma se dostává do popředí badatelského zájmu a zvlášt' od konce minulého století prodělává rychlý rozvoj. Je nutné připomenout, že během relativně krátké doby vedla třicetiletá válka k obrovské recesi ve střední Evropě a naopak k dominanci nových zemí, jako např́iklad Švédska. Přestože konflikt v rámci raně moderní historie představoval krátkodobou událost, z hlediska dlouhodobého změnilo klima, válka a nemoci Evropu natolik, že pozůstatky válečného běsnění jsou v krajině pozorovatelné dodnes a je nutné studovat je archeologickými prístupy.

Tento článek byl podpořen grantem GAČR: GA15-03380S: Proměněná země. Interdisciplinární výzkum vlivu třicetileté války na venkovskou krajinu Čech (2015-2017).

\section{Internetové zdroje}

Prerovsky.denik.cz: Dostupné z: https://prerovsky.denik.cz/zpravy_region/objev-stoleti-archeologove-v-prerove-nasli-bratrskou-skolu-20120720.html, cit. 21. 11. 2018.

Technet.idnes.cz: Dostupné z: https://technet.idnes.cz/30leta-valka-tabor-kosterni-nalez-divka-a-chlapec-f56-/veda.aspx?c=A180913_131204_veda_kuz, cit. 22. 11. 2018.

\section{Televizní reportáž}

Reportáž ČT24 ze dne 24. 8. 2018: Dostupné z: https://ct24.ceskatelevize.cz/ regiony/2574505-v-pribicich-odkryvaji-stovky-hrobu-habanu-prvni-kost-vykopali-uz-pred-40-lety.

\section{Prameny a literatura}

AF GEIJERSTAM, J.-NISSER, M. (edd.), 2011: Swedish Mining and Metalworking. Past and Present. Norrköping.

ALTOVÁ, B. a kol., 2007: Altová, B.-Alt, J.-Matoušek, V.-Šimek, J., Krajinná panoramata bitvy u Jankova v Theatru Europaeu, ASČ 11, 589-633.

ALTOVÁ, B. a kol., 2010: Altová, B.-Matoušek, V.-Kössl, A.-Šimek, J., Bitva na Bílé hoře na rytinách Jana Sadalera a v Theatru Europaeu. In: Ecce Homo. In memoriam Jan Fridrich. Knižnice české společnosti archeologické (Semrádová, K.-Fridrichová-Sýkorová, I., edd.), 224-238. Praha. 
ANSORGE, J., 2007: Bestattungen mit Tabakpfeifen aus der Zeit des Dreißigjährigen Krieges in Vorpommern, Knasterkopf 19, 37-40.

- 2010: Ein Massengrab aus der Zeit des Nordischen Krieges auf dem ehemaligen Frankenhornwerk in Stralsund, Archäologische Berichte aus Mecklenburg-Vorpommern 17, 122-135.

BÁRTL, S.-KOSTELECKÝ, J., 1993: Ďáblova bible. Tajemství největší knihy světa. Praha.

BAUER, R.-HAUPT, H., 1976: Das Kunstkammer-Inventar Kaiser Rudolfs II. 1607-1611, Jahrbuch der kunsthistorischen Sammlungen in Wien 72, 1-143.

BENEŠ, A., 1991: Nález cínových holeb u Hut'ského Dvora na Šumavě, Výběr z prací členů Historického klubu při Jihočeském muzeu v Českých Budějovicích 28, č. 2, 129-135.

BENEŠ, J.-KUBŮ, F.-TÖRÖK, J., 1995: Soubor militarií z počátku třicetileté války z Volarských šancí, AR XLVII, 461-480.

BENGTSSON, A., 1995: Silver och smycken på Skokloster. Bålsta.

BERG-HOHBOHM, S., 2008: Ein anderer Blick auf die Schlacht von Alerheim. Massengrab aus Dreißigjährigen Krieg entdeckt, Denkmalpflege Informationen, Aufgabe B, Nr. 140, 21.

BERG-HOHBOHM, S.-WEDEKIND, F., 2008: Gold erworben, den Tod gefunden, Archäologie in Deutschland, Heft 5, 40.

BEZDĚK, A. a kol., 2016: Bezděk, A.-Houfková, P.-Kovačiková, L.-Šálková, T., Bioarcheologická analýza mincovního depotu. In: Chvojka, J.-John, J.-Thomová, Z. a kol., Bošilecký poklad, 18-25. České Budějovice.

BLAŽKOVÁ, K. (ed.), 2011: Bitva u Rakovníka. Rakovník.

BLAŽKOVÁ, T.-MATOUŠEK, V., 2008: Plány obléhání města Tábora v době třicetileté války, ASČ 12, 849-869.

BLAŽKOVÁ-DUBSKÁ, G., 2005: Archeologický výzkum novověkého pohřebiště u Jízdárny. In: Pohřbívání na Pražském hradě a jeho předpolích. Díl 1. Castrum Pragense 7 (Tomková, K., ed.), 403-408. Praha.

BOSSEN, C., 2006: War as Practise, Power, and Processor: A Framework for the Analysis of War and Social Structural Change. In: Warfare and Society. Archaeological and Social Anthropological Perspectives (Otto, T.-Thrane, H.-Vnadkilde, H., edd.), 89-102. Aarhus.

BOUDA, J.-KOČÁR, P., 2011: Merklín - ulice 1. máje, raně novověké spáleniště studované pomocí environmentální archeologie, AZČ 2, 173-181.

BRAUN, P., 1995: Rozvadov, okr. Tachov, Výzkumy v Čechách 1990-1992, 313.

BREJCHA, R., 2013: Evaluace archeologického potenciálu lesního prostředí jihozápadní části Radečské vrchoviny s využitím lidarových dat. In: Archeologie a letecké laserové skenování (Gojda, M.John, J., edd.), 200-220. Plzeň.

BRION, M., 2014: Belegering van Leuven 1635. Kwartier van de prins van Oranje. De methodologische aanpak van het onderzoek van een 17 de eeuwse kampplaats. Poster 14. November. Dostupné z: https:// www.academia.edu/9715690/Belegering_van_Leuven_1635_Kwartier_van_de_prins_van_Oranje, cit. 7. 12. 2018.

BROCK, T.-HOMANN, A., 2011: Schlachtfeldarchäologie. Auf den Spuren des Krieges. Stuttgart.

BROOKER, R. (ed.), 2007: Landeszeughaus Graz, Austria. Radschloss Sammlung/Wheellock Collection. Hong Kong.

BŘICHÁČEK, P.-METLIČKA, M.-PAVLÍK, D., 2016: Drobný mincovní nález ze Všerubského průsmyku z doby třicetileté války, AZČ 10, 193-200.

BÜNTGEN, U. et al., 2011: 2500 Years of European Climate Variability and Human Susceptibility, Science 331, 578-582. https://doi.org/10.1126/science.1197175

BUREŠ, M., 2002: Zpráva o zjištovacím archeologickém výzkumu. Nám. OSN - Praha 9 - Vysočany, ulož. v archivu společnosti Archaia Praha, z. ú.

- 2003: Nálezová zpráva ze zjištovacího archeologického výzkumu „Nová Liboc“ v Praze 6, ulož. v archivu společnosti Archaia Praha, z. ú.

- 2017: Bílá hora - bojiště třicetileté a studené války - Der Weiße Berg - ein Schlachtfeld des Dreißigjährigen und des Kalten Krieges, AH 42, 245-259.

BUSL, F., 2003: Die Tillyschanze auf dem Steinberg bei Bärnau, Die Oberpfalz 91, 345-346.

CABRERA TEJEDOR, C., 2010: Re-conservation of wood from the seventeenth-century Swedish warship the Vasa with alkoxysilanes: A re-treatment study applying thermosetting elastomers. College station. Nepubl. disertační práce, Office of Graduate Studies of Texas A\&M University. 
CEDERLUND, C. O.-HOCKER, F., 2006: Vasa I. The Archaeology of Swedish Warship of 1628. Stockholm.

CODREANU-WINDAUER, S., 1988: Ausgrabungen in der St.-Peters-Kirche zu Niedertraubling, Das archäologische Jahr in Bayern 1988, 149-150.

- 1993/1994: Die Ausgrabungen in der St.-Peter-Kirche zu Niedertraubling bei Regensburg, Bericht der Bayerischen Bodendenkmalpflege 34/35, 265-290.

COSACK, E., 2006: Spuren eines Heerlagers vor den Toren von Sarstedt, Lkr. Hildesheim, Nachrichten Niedersachsens Urgeschichte 75, 241-252.

CVRKOVÁ, M., 2001: Kuchyňská a stolní keramika v době renesance. In: Renesanční sochařství a malířství v severozápadních Čechách. Sborník příspěvků z kolokvia v Muzeu města Ústí nad Labem ve dnech 25.-26. listopadu 1999 (Hrubá, M.-Hrubý, P., edd.), 267-279. Ústí nad Labem.

CVRKOVÁ, M.-ČERNÁ, E., 2007: Sklo z počátku novověku z Ústí nad Labem - Předmostí čp. 43, Historické sklo 4, 77-90.

ČAPEK, L., 2011: Studium sídelních struktur na Českobudějovicku se zaměřením na zaniklé středověké vesnice, AH 36, 351-372.

ČAPEK, L.-PREUSZ, M., 2012: Chov ovcí, ovčíny a sociální struktura ovčího řemesla ve středověku a novověku v Čechách a na Moravě, Kuděj 2, 6-35.

- 2019: Středověké a novověké hrnčířské pece v Čechách a na Moravě - kritické zhodnocení výpovědních možností studia - Mittelalterliche und neuzeitliche Töpferöfen in Böhmen - eine kritische Auswertung der Aussagemöglichkeiten von Studien, AH 44 (v tisku).

ČERNOŠ, Š.-HEJHAL, P., 2012: Archaeological excavations of Jihlava's Early Modern fortifications (2003-2010), Studies in Post-Medieval Archaeology 4, 389-402.

DALITZ, S.-GRUPE, G.-JUNGKLAUS, B., 2012: Das kleinste Massengrab Brandenburgs: Die drei Toten aus dem Dreißigjährigen Krieg aus der Dominsel der Stadt Brandenburg/Havel. 21. Jahresbericht, Historischer Verein Brandenburg (Havel), 67-80.

DERNER, K., 2018: Archeologické nálezy z vyhořelé bašty vnějšího opevnění Kadaně, příspěvek k poznání hmotné a duchovní kultury měšt’anů v 17. století - Archäologische Funde aus der abgebrannten Bastei der Außenbefestigung der Stadt Kadaň (Kaaden). Ein Beitrag zur materiellen und geistigen Kultur der Bürger im 17. Jahrhundert, AH 43, 145-161.

DeVRIES, K., 1998: Gunpowder Weaponary and the Rise of the Early Modern State, War in History 5, č. 2, 127-145. https://doi.org/10.1177/096834459800500201

DOBRÝ, J., 2011: Dendrologická analýza zbytků z bojiště u Rozvadova z roku 1621, Sborník Muzea Českého lesa v Tachově 32, 13-17.

- 2013: Zpráva o dendrochronologické analýze uhlíků z výzkumu Rozvadov 2011, Bastion I., Sborník Muzea Českého lesa v Tachově 33, 15-16.

DOHNAL, M.-VAŘEKA, P., 1997: Výzkum novověké usedlosti v Srlíně (okr. Písek) - svědectví archeologických a písemných pramenů, AVJČ 10, 84-106.

DÖRFLER, W.-STIEWE, H., 2010: Bauernhäuser aus dem Dreißigjährigen Krieg und Viehaufstallung, Der Holznagel 36, č. 2, 15-23.

DRAGOUN, D.-MATOUŠEK, V.-TUČEK, J., 2007: Experimentální stavba modelu polního opevnění ze třicetileté války v Uhřínově, Živá archeologie 8, 61-66.

DRGÁČOVÁ, A., 2010: Ikonografie dobývání Litoměřic z roku 1640. In: Polní opevnění od třicetileté války do roku 1945 (Balský, J.-Slavík, J., edd.), 19-22. Jaroměř - Josefov.

DUDKOVÁ, V.-ORNA, J., 2009: A description of medical equipment in the Early Modern period on the basis of finds from the cesspit at house no. 289 in Pilsen, Studies in Post-Medieval Archaeology 3, 501-508.

DUDKOVÁ, V.-ORNA, J.-NETOLICKÝ, P., 2014: Špitální kostel sv. Máří Magdalény v Plzni - Das Spitalareal St. Maria Magdalena in Pilsen, AH 39, 221-239.

- 2015: Část historická. In: Od špitálu. Archeologické poznání vývoje lokality „U Zvonu“ v Plzni (Dudková, V.-Orna, J., edd.). Plzen̆.

DURDÍK, T., 1976: Čtyřúhelníkové valy („Viereckschanze“) Kokrdov u Rakovníka, AR XXVIII, 544547, 599-600.

EICKHOFF, S.-SCHOPPER, F. (edd.), 2012: Wittstock 1636 - Ihre letzte Schlacht. Leben im Dreißigjährigen Krieg. Theiss Verlag.

ENGERISSER, P., 2007: Kalibertabellen und abmessungen für Feuerwaffen von 1600 bis 1650. Dostupné z: http://www.engerisser.de/Bewaffnung/Kaliber_kompl.pdf, cit. 28. 9. 2017.

ENGLUND, P., 2008: Stř́ibrná maska. Pohled na život královny Kristiny. Praha. 
FIALOVÁ, V., 1958: Historicko-archeologický výzkum tvrze a kostela v Kralicích n. O. v roce 1957, ČMM, vědy společenské 43, 3-16.

- 1959: Ein Letternfund aus dem XVI. Jahrhundert in Kralice nad Oslavou, Gutenberg-Jahrbuch 34, 85-91.

- 1961: Bronzenadeln aus einer Buchdruckerei 16. Jahrhunderts, Gutenberg-Jahrbuch 36, 136-141.

FIEDLEROVÁ, E.-MATOUŠEK, V., 2012: Rytina obléhání Olomouce v letech 1643-1644 v díle Matthiase Meriana, Olomoucký archivní sborník 10, 54-72.

FOARD, G., 2012: Battlefield Archaeology of the English Civil War. Oxford.

FORBELSKÝ, J., 2006: Španělé, Říše a Čechy v 16. a 17. století. Osudy generála Baltasara Marradase. Praha.

FRIEDERICH, S.-SCHRÖDER, O., 2015: Das Massengrab von Lützen. In: Krieg. Eine Archäologische Spurensuche (Meller, H.-Schefzik, M., edd.), 399-404. Halle (Saale).

FRÖHLICH, J., 1991: Středověká opevnění kolem hradu Zvíkova, CB 2, 155-159.

- 1996: Doplněk k souboru militárií z třicetileté války z Volarských šancí, AR XLVIII, 519-521.

- 2000: Historická opevnění jižní zemské hranice, Výběr 37, 285-290.

- 2010: Městský hřbitov u farního kostela Narození Panny Marie v Písku (výzkum 1994-2006), JSH 79, 47-61.

FROLÍK, J.-MUSIL, J., 2010: Záchranný archeologický výzkum v Hradební ulici v Chrudimi v roce 2006, Chrudimský vlastivědný sborník 14, 3-28.

FRÝDA, F., 1998: Plzeňská městská zbrojnice I. Plzeň.

- 2007: Nálezy renesančního skla z Plzně, Historické sklo 4, 33-65.

GAŽI, M., 2005: Huertovský (v)klad. K interiérovému vybavení píseckého kostela Narození Panny Marie v první polovině 17. století, Časopis společnosti přátel starožitností českých 43/113, č. 2, 65-74.

GOJDA, M., 2013: Výzkum, dokumentace a mapování novověkých polních opevnění prostřednictvím letecké prospekce, fotografie a laserového skenování. In: Gojda, M.-John, J. a kol., Archeologie a letecké laserové skenování krajiny, 38-48. Plzeň.

GREEN, J. N., 2004: Gunpowder: Alchemy, Bombards and Pyrotechnics: The history of the Explosive that Changed the Worlds. New York.

GRINDER-HANSEN, P., 2002: Guides to the National Museum. Danisch Middle Ages and Renaissance, 186-193. Copenhagen.

GROSSMANNOVÁ, D., 2014: Boskovický poklad (nález mincí z třicetileté války). Brno.

GROTHE, A., 2015: Auf die Kugeln Geschaut - Schlachtfeldarchäologie in Lützen. In: Krieg. Eine Archäologische Spurensuche (Mehler, H.-Schefzik, M., edd.), 386. Halle (Saale).

HAVEL, J., 1980: Hromadný hrob bělohorských bojovníků, Archaeologia Pragensia 1, 227-230.

HILDEBRAND, K. G., 1992: Swedish iron in the Seventeenth and Eighteenth Centuries. Export Industry before the Industrialization. Södertälje.

HLUBEK, L.-FALTÝNEK, K. 2016: Soubor raně novověkých kachlů z Chořelic (okr. Olomouc), Zprávy Vlastivědného muzea v Olomouci 312, 113-124.

HLUBEK, L.-ŠLÉZAR, P. 2016: Raně novověká kolekce kachlů ze Zahradní ulice v Litovli, Sborník Národního památkového ústavu územního odborného pracoviště v Olomouci, 51-65.

HJORTSJÖ, C. H., 1966: Queen Christina of Sweden. A medical/anthropological investigation of her remains in Rome. Lund.

HOCKER, F., 2011: Vasa. Stockholm.

HOFMANN, G., 1964: Soupis železných hutí a hamrů v Čechách v období feudalismu. Praha.

- 1968: Komorní železárny na Podbrdsku. Praha.

HÖFT, T., 1998: Welt aus Eisen. Waffen und Rüstungen aus dem Zeughaus in Graz. Wien - New York.

HRACHOVÁ, H., 2011: Barokní Rokycany v letech 1618-1784. In: Rokycany (Hrachová, H., ed.), 81-115. Praha.

HRNČIŘÍK, P., 2005: „La battala de Honnecourt“ de Peeter Snayers in the Prado, Boletín del Museo del Prado 41, 60-69.

- 2011: Příspěvek k nálezům munice do ručních palných zbraní v prostoru bojiště Rozvadov 1621. In: V. Matoušek a kol., Zpráva o 1. sezóně systematického archeologického výzkumu bojiště z roku 1621 u Rozvadova, Sborník Muzea Českého lesa v Tachově 32, 17-21.

- 2013: Příspěvek k nálezům munice v prostoru bojiště Rozvadov 1621 - souhrn za období 2010-12, Sborník Muzea Českého lesa v Tachově 33, 17-32. 
HUISMAN, D. J. et al., 2012: Huisman, D. J.-Van Doesburg, J.-Van Os, B. J. H.-Kroeze, A.-Mooren, S.Kniep, J., Bullets over Gennep. Using compositional variation in lead musket balls in battlefield archaeology. Cultural Heritage Agency. Ministry of education, Culture and Science (poster).

HUML, V., 1971: Nález renesanční keramiky v Praze Na Slovanech, AR XXIII, 222-226.

- 1995: Rudolfínská lékárna Matyáše Borbonia na Koňském trhu očima archeologie. Katalog k výstavě. Praha.

CHALOUPKA, J., 1977: K funkci bronzových špendlíků z kralické tiskárny, Z kralické tvrze 9, $13-18$.

CHVOJKA, J.-JOHN, J.-THOMOVÁ, Z., 2016: Bošilecký poklad. České Budějovice.

ILISCH, P., 1998: Geld und Münze während des Dreißigjährigen Krieges. In: 1648. Krieg und Frieden in Europa (Bußmann, K.-Schilling, H., edd.), 345-351. Münster - Osnabrück.

- 2002: Ein Münzschatzfund aus dem Dreißigjährigen Krieg in Hagen-Holthausen, Hohenlimburger Heimatblätter für den Raum Hagen und Iserlohn 63, 411-415.

JANÁČEK, J., 2003: Pád Rudolfa II. Praha.

JANATA, T.-MATOUŠEK, V.-ZIMOVÁ, R., 2013: Historicko-kartografický výzkum bojiště třicetileté války: rytina obléhání Plzně v roce 1618, Kartografické listy 21, 18-26.

JANSKÁ, E., 1966: Hromadný hrob bělohorských bojovníků, Staletá Praha 2, 107-110.

JARVIS, W. E., 2003: Time Capsules. A Cultural History. Jefferson - London.

JEŽEK, M.-ZAVŘEL, J., 2010: Prubířské kameny mezi archeologickými nálezy, AR LXII, 608-628.

JIŘÍK, J. a kol., 2010: Jiřík, J.-Kypta, J.-Pták, M.-Simota, V.-Š́álková, T., Archeologický výzkum zaniklého objektu u domu čp. 24 v Horosedlech u Mirovic v roce 2009 a 2010. Nepublikovaný rukopis NZ uložený v Prácheňském muzeu v Písku.

JIŘÍK, J. a kol., 2016: Jiřík, J.-Pták, M.-Š́lková, T.-Hlásek, D.-Hiltscher, T., Archeologické výzkumy v historickém jádru města Písku v letech 2010-2015. In: Prácheňské muzeum města Písku v roce 2015, 47-79. Písek.

JOHN, J., 2012: Řakom (okr. Klatovy) - eneolitické ohrazení, anebo pozůstatek třicetileté války? In: Polní opevnění od třicetileté války do roku 1945 (Slavík, J., ed.), 33-36. Josefov.

JOHN, J.-KOLÁŘ, D., 2017: Poklady z domu U Slabých v Týně nad Vltavou. České Budějovice.

JUNGKLAUS, B., 2012: Pestopfer? Drei Bestattungen aus dem 17. Jahrhundert auf der Dominsel Brandenburg an der Havel, Archäologie in Berlin und Brandenburg 2011, 132-135.

JUNGKLAUS, B.-KONZE M.-SAMARITER, R., 2012: Die Stralsunder Stadtbefestigung, Strale Sunth - Stadt-Schreiber-Geschichte(n) 2, 98-103.

JUNGKLAUS B.-PREHN, B., 2011: Ein Soldatenmassengrab vom Friedländer Tor in Neubrandenburg aus dem Jahre 1631 und dessen anthropologische Untersuchung, Neubrandenburger Mosaik 35, 10-33.

JUSTOVÁ, J., 2002: Chalupovský manský dvůr v Libici nad Cidlinou. Archeologický př́íspěvek k poznání stř̌edověké a raně novověké vsi Libice. Část. II, CB 8, 381-392.

KAMENICKÁ, E., 2009: Zjištění na hradě Krasíkov-Švamberk, Hláska 20, č. 2, 17-19.

KARLSSON, B., 1998: Komenský a válečná kořist na švédském zámku Skokloster (1), Theologická revue 7 , č. 2, 27-32.

- 1998a: Komenský a válečná kořist na švédském zámku Skokloster (2), Theologická revue 7/6, 91-95.

- 2000: Bohemika a válečná kořist v některých knihovnách a zámcích ve Švédsku. In: Češi za hranicemi na přelomu 20. a 21. století: sympozium o českém vystěhovalectví, exulantství a vztazích Čechů k domovu 29.-30. června 1998, 259-271. Praha.

KERSCHER, H., 1994: Zur Fortifikation des Mansfeldischen Pagere bei Waidhaus im Jahr 1621, Oberpfälzer Heimat 38, 1-9.

- 1998: Zur Topographie, Kartographie und Baugeschichte der Tillyschanz bei Eslarn, Lkr. Neustadt a. d. Waldnaab, Beiträge zur Archäologie in der Oberpfalz 2, 423-448.

KILIÁN, J., 2010: Martin Maxmilián z Golče. Císařský generál ve víru třicetileté války. České Budějovice.

KINDER, U., 2013: Der Befestigungsbau im Landkreis Tirschnreuth. Arbeiten zur Archäologie Deutschlands. Band 28. Erlangen.

KLÁPŠTĚ, J., 1978: Středověké osídlení Černokostelecka, PA LXIX, 423-475.

KLEBERG, T., 1984: The Silver Bible at Uppsala. Uppsala.

KODERA, P., 2009: Zaniklá osada Vojkov na Černokostelecku v raně novověkých písemných pramenech, Kuděj 11, č. 1, 55-62.

KOLǍ̌ÍK, V.-MERTA, D.-PEŠKA, M., 2015: Archeologie živé vesnice. Poznámky ke stavu výzkumu v roce 2015, Museum vivum 2014/2015, č. 10, 9-26. 
KOLAŘÍK, V.-MERTA, D.-POKORNÝ, J., 2014: Bývalá rychta v Sebranicích čp. 36. Počátek systematického výzkumu vesnické usedlosti. In: Dějiny staveb 2014. Sborník prř́spěvků z konference Dějiny staveb, 211-220. Plzeň.

KONRÁDOVÁ, M., 2017: Archeologie novověkých vojenských ležení, táborů a polních opevnění v jižních Čechách. České Budějovice. Nepubl. diplomová práce, ulož. na FF JU v Českých Budějovicích.

KONRÁDOVÁ, M. a kol., 2017: Konrádová, M.-Vondrovský, V.-Pták, M.-John, J.-Kocina, P., Nově identifikovaná novověká polní opevnění na Lhenicku (okres Prachatice) - Eine neu identifizierte Feldbefestigung in der Region Lhenice (Bezirk Prachatice), AH 42, 261-277.

KOSTLÁN, A., 1986: Nálezy mincí českého prostředí z období třicetileté války jako historický pramen. Př́íspěvek k aplikaci matematických metod při rozboru hromadných pramenů pozdního feudalismu, Numismatický sborník 17, 191-236.

KOUCKÝ, K.-STOLZ, D.-STOLZOVÁ, D., 2004: Záchranný archeologický výzkum novověkých situací v Hořovicích, ASČ 8, 787-799.

KOVANDOVÁ, M.-MATOUŠEK, V., 2005: Terénní dokumentace Švédské šance nad hradem Kynžvartem - Terraindokumentation der Schwedeneschanze oberhalb der Burg Königswart, Sborník Chebského muzea 2004, 61-66.

KOVÁŘ, D., 2014: Dělostřelecká reduta v Rohozné na Pelhřimovsku, ČSPS 122, č. 4, 218-226.

KRAJÍC, R., 2007: Archeologie postmedieválního období v jižních Čechách. Archeologie na Pomezí, AVJČ 4, 137-174.

KRAJÍC, R.-MĚŘÍNSKÝ, Z.-VAŘEKA, P., 2017: Archaeology of the 16th-20th century in the Czech Republic, AH 42, 367-399.

KRAJÍC, R.-MOŘKOVSKÝ, T., 2005: Nález lidských kosterních pozůstatků na táborském hradě, Ve službách archeologie 6, 397-416.

KRÁLÍKOVÁ, M., 2004: Devocionálie jako předměty zbožnosti v hrobech ze 17.-19. století. Nepubl. rigorózní práce, ulož. na Katedře antropologie PřF MU, Brno.

KRENN, M., 1989: KG Unterneudorf, Fundberichte aus Österreich 28, 277-278.

- 1992: Die Schanzanlagen am Oberhaag, KG Unterneudorf - OG Schlägl - VB Rohrbach, Oberösterreich. Schlägl - Wien.

KRENN, P. (ed.), 2000: Imperial Austria. Steierische Kunst- und Waffenschätze aus vier Jahrhunderten. Ausstellungskatalog Burg Rabenstein - Frohnleiten. Weizen.

KRU゚L, M., 2013: Stavebněhistorický vývoj jablunkovských šancí, Svorník 11, 113-119.

- 2017: Obrana horských přechodů na Moravu a do Uher na př́íkladu hradeckých a jablunkovských šancí - Der Schutz von nach Mähren und Ungarn führenden Gebirgspässen am Beispiel der Grätzer und Jablunkauer Schanzen, AH 42, 561-577.

KRŮL, M.-NOVÁKOVÁ, P., 2005: Jablunkovské šance. Český Těšín.

KRUSE, H., 1996: Der Zinnfund von Behren-Lübchin, Landkreis Güstrow, Mecklenburg Jahrbuch 111, $169-182$.

KUPKA, V. a kol., 2006: Pevnosti a opevnění v Čechách, na Moravě a ve Slezsku. Praha.

KYPTA, J.-RICHTEROVÁ, J., 2004: Příspěvek k interpretaci reliktů obléhacích prací u hradu Zvíkova, AVJČ 17, 253-260.

LANG, M., 2011: Zaniklé alaunové hutě na Rokycansku a severním Plzeňsku, Z dějin hutnictví 41, 44-47.

LE BLANC, F. Y.-FAUCHERE, N., 2007: La Route des fortifications en Atlantique: Les étoiles de Vauban. Paris.

LIPPMANN, W., 1998: Architektur zur Zeit des Dreißigjährigen Krieges: Kirchen und Schlösser im deutschsprachigen Raum. In: 1648: Krieg und Frieden in Europa, 271-279. Münster.

LOSKOTOVÁ, I., 1997: Keramika ze švédského zákopu před Brnem - Die Keramikfunde aus einer schwedischen Schanze vor Brno, AH 22, 309-313.

LOSKOTOVÁ, I.-HANÁK, V., 1995-1996: Švédský zákop před Brnem, Forum Brunense 7, 143-151.

LUDWIG, R.-CÜPPERS, B., 2005: Nach abgeschlossener Restaurierung: Die Arkebuse aus dem Belagerungsjahr 1622, Kunstwerk des Monats 248, 1-2.

MACKŮ, P., 2015: Švédské šance, novověké polní opevnění. In: 100 zajímavých archeologických lokalit Moravy a Slezska (Tomášek, M., ed.), 111-114. Praha.

MAJER, J., 2004: Rudné hornictví v Čechách, na Moravě a ve Slezsku od pravěk do konce 20. století. Praha.

MALINA, O., 2013: Lidar a interpretace historického antropogenního reliéfu v zázemí dvou kostelů na Černokostelecku. In: Archeologie a letecké laserové skenování krajiny (Gojda, M.-John, J., edd.), 159-172. Praha. 
MARSTALLER, T., 2008: Der Wald im Haus. Zum Wechselspiel von Holzressourcen und Hausbau, Das Mittelalter 13, č. 2, 63-84. https://doi.org/10.1524/mial.2008.0017

MARTÍNEK, J. a kol., 2013: Martínek, J.-Létal, A.-Peška, J.-Kalábek, M.-Vrána, J.-Šlézar, P., Identifikace starých cest a dalších objektů za pomoci LLS. In: Gojda, M.-John, J. a kol., Archeologie a letecké laserové skenování krajiny, 228-240. Plzeň.

MATĚJKOVÁ, K., 2012: Soubor novověkých květníků z Valdštejnského casina u Jičína, ZPP 72, č. 3, $159-165$.

MATĚJKOVÁ, K.-SVOBODOVÁ, L., 2017: Keramika zahrady valdického letohrádku. In: Architektura Albrechta z Valdštejna. Italská stavební kultura v Čechách v letech 1600-1635. Díl 1, 577-580. Praha.

MATIEGKA, J.-MALÝ, J.-BERGL, J., 1934: Tělesná povaha Albrechta z Valdštejna. Praha.

MATOUŠEK, V., 2004: Výstavba polního opevnění u Olbramova na Tachovsku, (Re)konstrukce a experiment v archeologii - Živá archeologie 5, 260-277.

- 2006: Třebel. Obraz krajiny s bitvou. Praha.

- 2006a: Building a Model of a Field Fortification of the „Thirty Years War“ near Olbramov, Czech Republic. In: Past Tense. Studies in the Archaeology of Conflict (Pollard, T.-Banks, I., edd.), 115-132. Leiden - Boston.

- 2011: Zpráva o 1. sezóně systematického archeologického výzkumu bojiště z roku 1621 u Rozvadova, Sborník Muzea Českého lesa v Tachově 32, 3-13.

- 2011a: Plány obléhání Brna v roce 1645 ve světle mezioborového studia, ASČ 15, 609-621.

- 2011b: Česká, moravská a slezská města v ikonografických pramenech ke třicetileté válce, HG 37, č. 1, 69-85.

- 2012: Archäologische Erforschung der Schlachtfelder des Dreissigjährigen Krieges auf dem Gebiet der Tschechischen Republik. In: Die blut'ge Affair' bei Lützen. Wallensteins Wende (Reichel, M., ed.), 283-293. Wettin - Löbejün.

- 2013: Předběžná zpráva o 2. a 3. sezóně archeologického výzkumu bojiště u Rozvadova z roku 1621, Sborník Muzea Českého lesa v Tachově 33, 3-14.

- 2015: Poznámky k terénnímu studiu polních opevnění ze 17. a 19. století. Zkušenosti z českých zemí, AZČ 9, 70-82.

- 2017: Archeologický výzkum bojišt' a vojenství raného novověku v Českých zemích. Historie, stav poznání, diskuze - Die archäologische Erforschung von Schlachtfeldern und des Militärwesens des frühen Mittelalters in den Ländern Böhmens: Geschichte, Kenntnisstand, Diskussionen, AH 42, 233-243.

MATOUŠEK, V.-BLAŽKOVÁ, T., 2012: The image and reality of battlefields from the Thirty Year's War. A preliminary report on a project for the systematic study of engravings of the battlefields from the Thirty Year's War in the territory of the Czech Republic, Studies in Post-Medieval Archaeology 4, 269-288.

MATOUŠEK, V.-BOHÁČ, J., 2010: Plány obléhání Chebu v roce 1647 v díle Theatrum Europaeum, ASČ 14, 449-466.

MATOUŠEK, V.-HRNČIŘÍK, P.-ŠÁMAL, Z., 2018: Rozvadov 1621. Výzkum bojiště třicetileté války. České Budějovice.

MATOUŠEK, V.-SCHEUFLER, V., 1980: Nálezy novověké keramiky v Berouně, Vlastivědný sborník Podbrdska 18, 53-57.

- 1983: Raně novověké keramické zboží ve světle archeologických výzkumů v Berouně - Frühneuzeitliche Berouner Waere im Lichte archäologischer Forschung, AH 8, 189-196.

MATOUŠEK, V.-SCHEUFLER, V.-ŠTAJNOCHR, V., 1985: Berounské majoliky, ČNM A 154, 126-139.

MATOUŠEK, V.-ZIMOVÁ, R.-JANATA, T., 2012: Optický klam generála Kleinträtla. Rytina bojů u Teplé v záŕí 1647 ve světle mezioborového studia. In: Krajina jako historické jeviště. K poctě Evy Semotanové (Chodějovská, E.-Šimůnek, R., edd.), 63-80. Praha.

MATOUŠEK, V. a kol., 2007: Matoušek, V.-Šimek, J.-Altová, B.-Karlík, P., Pohled na zámek Brandýs nad Labem a opevnění švédského tábora v prostoru Staré Boleslavi z roku 1640 v díle M. Meriana, HG 34, 93-148.

MATOUŠEK, V. (ed.), 2018: Třebel 1647. A Battlefield of the Thirty Year's War from the Perspective of History, Archaeology, Art-History, Geoinformatics and Ethnology. Praha.

MAZANIK, J., 2012: Analýza rytiny historického bojiště Plzeň. Nepubl. diplomová práce, ulož. na Katedře mapování a kartografie Fakulty stavební ČVUT v Praze.

MAZUCH, J., 2012: Doklady novověkých aktivit v prostoru zaniklého raně středověkého mocenského centra Mikulčice-Valy, Jižní Morava 48, sv. 51, 7-45. 
MEHLER, N., 2007: Tonpfeifen aus bayerischen Gräbern. Eine erste Bestandsaufnahme. In: Tonpfeifen als Grabfund. Knasterkopf (Kluttig-Altmann, R., ed.), Fachzeitschrift für Tonpfeifen und historischen Tabakgenuss 19, 28-32.

MELLER, H., 2009: Schlachtfeldarchäologie. Battlefield Archaeology. Halle an der Saale.

MELLER, H.-SCHEFZIK, M. (edd.), 2015: Krieg. Eine Archäologische Spurensuche. Begleitband zur Sonderaustellung im Landesmuseum für Vorgeschichte Halle (Saale) 6. November 2015 bis 22. Mai 2016. Halle an der Saale.

MENOUŠKOVÁ, D.-MĚŘÍNSKÝ, Z., 2008: Krása, která hřeje. Výběrový katalog gotických a renesančních kachlů Moravy a Slezska. Uherské Hradiště.

MERTA, D.-KOLǍ̌ÍK, V.-KMOŠEK, M., 2016: Archeologický výzkum lidových staveb - roubený dům čp. 97 v Čisté. In: Průzkum a dokumentace památek lidové architektury (Kmošek, J.-Křenková, Z.-Bryol, R., edd.), 96-113. Rožnov pod Radhoštěm - Sebranice.

METLIČKA, M.-ORNA, J.-ZELENKA, A., 2008: Záchranný archeologický výzkum na hradě Krasíkov, SZM 19, 132-155.

MICHL, E., 2017: Ausgrabungen in der Wüstung Lindelach. Ein archäologischer Beitrag zur Siedlungsforschung und Sachkultur des Spätmittelalters und der frühen Neuzeit. Bonn.

MILITKÝ, J., 1996: Depot mincí z počátku třicetileté války z Thrových Svinů na Českobudějovicku, Výběr 33, 239-245.

- 1997: Depot mincí z počátku třicetileté války z Trhových Svinů, okr. České Budějovice, AVJČ 10, 107-132, 170-172.

MISTEREK, K., 2012: Ein Massengrab aus der Schlacht von Alerheim am 3. August 1645, Bericht der Bayerischen Bodendenkmalpflege 53, 361-391.

MITCHELL, P., 2013: Vienna. The Architecture of Absolutism. In: Historical Archaeology in Central Europe. Society for Historical Archaeology. Special Publication No. 10 (Mehler, N., ed.), 365-378. Rockville.

MITTELSTRAB, T., 2007: Archäologie der Gegenreformation. Spuren der nachtridentischen Erneurung der katholischen Kirche in archäologischen Befunden aus Oberbayern. In: Rainer Schreg: Archäologie der frühen Neuzeit. Mitteilungen der Deutschen Gesellschaft für Archäologie des Mittelalters und der Neuzeit 18, 9-20. Paderborn.

MORÁVEK, J., 1933, 1934/1935, 1937: Nově objevený inventář rudolfínských sbírek na Hradě pražském, PA - skupina historická, NŘ 2, 3, 1933; 4-5, 1934/1935; 1937.

MUSIL, J., 2008: Soubor raně novověkých hliněných dýmek z Hradební ulice v Chrudimi, Chrudimský vlastivědný sborník 12, 3-35.

- 2010: Nález raně novověké prachovnice z Chrudimi - Hradební ulice, Chrudimský vlastivědný sborník 14, 181-190.

-2012: A contribution to understanding of the northeast part of the town fortifications in Chrudim on the basis of written, iconographic, cartographic and material sources, Studies in Post-Medieval Archaeo$\log$ 4, 365-388.

- 2015: Nález kolečkového zámku palné zbraně z hradu Košumberka (okr. Chrudim), CB 15, 94-105.

- 2016: Zpráva o záchranném archeologickém výzkumu provedeném na základě dohody č. 102/2016 na lokalitě Chrudim, Břetislavova ul., akce: MLK - rekonstrukce teras; Břetislavova 74 (IDAV: 67867). Ulož. v Regionálním muzeu v Chrudimi.

MUSIL, J.-NETOLICKÝ, P., 2012: Zaniklá středověká a raně novověká ves Bolešov v k. ú. Spačice, okres Chrudim, Pardubický kraj, Východočeský sborník historický 22, 73-114.

MUSIL, J.-NETOLICKÝ, P.-PREUSZ, M., 2018: Archeologický obraz událostí třicetileté války na Chrudimsku - Das archäologische Bild der Ereignisse des Dreißigjährigen Krieges in der Region Chrudim, AH 43, 281-309.

NICKLISCH, N. et al., 2015: Nicklisch, N.-Knipper, C.-Held, P.-Pickard, L.-Ramstahler, F.-Friedrich, S.-Alt, K. W., Die 47 Soldaten aus dem Massengrab - Ergebnisse der Bioarchäologischen Untersuchungen. In: Krieg. Eine Archäologische Spurensuche (Meller, H.-Schefzik, M., edd.), 405-420. Halle (Saale).

NOHEJLOVÁ-PRÁTOVÁ, E., 1957: Nález v Kralovicích u Plzně, Numismatický sborník 4, $218-221$.

NOVÁČEK, K., 2007: První sezóna průzkumu středověkého výrobního mikroregionu Strašicko. In: Opomíjená archeologie 2005-2006, 164-172. Plzeň.

NOVOTNÁ, K., 2013: Vltavotýnský poklad z doby na přelomu středověku a novověku. České Budějovice. Nepubl. bakalářská práce, ulož. v Ústavu dějin umění FF JU v Českých Budějovicích. 
NOVOTNÝ, B., 1967: Vyzvednutí pozůstatků maršála Raduita de Souches, obránce Brna proti Švédům, PV 1966, 56-57.

ORSER, Ch. E., Jr., 2008: The Global and the Local in Modern-World Archaeology. In: Constructing Post Medieval Archaeology in Italy: A New Agenda (Gelichi, S.-Librenti, M., edd.), 25-33. Firenze.

PADDENBERG, D., 2015: Was von Goldberg übrig blieb. Der Dreissgijährige Krieg abseits der grossen Schlachtfelder. In: Krieg. Eine Archäologische Spurensuche (Meller, H.-Schefzik, M., edd.), 441-442. Halle (Saale).

PAJER, J., 1974: K metodice hodnocení lidové keramiky z archeologických nálezů, Národopisné aktuality $11,169-184$.

- 1982: Hromadný nález ze začátku 17. století ve Strážnici. Strážnice.

- 1983: Počátky novověké keramiky ve Strážnici. Strážnice.

- 2006: Studie o novokřtěncích. Strážnice.

- 2011: Anabaptist Faience from Moravia 1593-1620. Catalogue of documents from institutional and private collections. Strážnice.

PANOCHOVÁ, I., 2006: Offiziere und Rivalen Albrecht von Waldsteins als Stifter von Bauwerken in der Zeit des Dreissigjährigen Kriegs in Böhmen und Mähren, Umění LIV, č. 6, 492-503.

PARKAN, F., 2008: Švédové v Čechách a na Moravě: pomníky konce třicetileté války u nás, Dějiny a současnost 30 , č. $6,21-23$.

PAVLÍK, Č.-VITANOVSKÝ, Z., 2004: Encyklopedie kachlů v Čechách, na Moravě a ve Slezsku. Ikonografický atlas reliéfů na kachlích gotiky a renesance. Praha.

PERTLWIESER, M., 1996: Die Toten von Lambach. In: Archäologie Österreichs 7/2, 49-59.

PETRÁŇ, J., 1995: Dějiny hmotné kultury II/1. Praha.

PETRÁŇOVÁ, L. (ed.), 1979: Př́íěhy Jindřicha Hýzrla z Chodů. Praha.

PETRÁŇOVÁ, L.-VAŘEKA, J., 1987: Vybavení vesnické zemědělské usedlosti v době předbělohorské na pozadí poddanských inventářu - Die Ausstattung des Bauerngehöfts in der Zeit vor der Schlacht am Weißen Berg (vor dem Hintergrund der Untertaneninventare), AH 12, 277-286.

PLUM, M., 2012: Archäologische Zeugnisse des Dreissigjährigen Krieges: Gräber von Gefallenen in Höchstadt a. d. Aisch und in Ederheim, Bericht der Bayerischen Bodendenkmalpflege 53, 393-402.

POSCHOLD, P., 2015: Geschichte der Kulturlandschaft. Entstehungsursachen und Steuerungsfaktoren der Entwicklung der Kulturlandschaft, Lebensraum- und Artenvielfalt im Mitteleuropa. Ulm.

PREKOP, F., 2016: Relikty obléhání Lokte z 15. a 17. století. Nepubl. rkp., ulož. v NPÚ ÚOP v Lokti.

PREUSZ, M., 2016: Novověké dýmky v jižních Čechách (Archeologická sbírka JČM v Českých Budějovicích, 2. část), AVJČ 29, 399-408.

- 2017: Keramika 16. a 1. poloviny 17. století v jižních a západních Čechách. Inovace a kontinuita hrnčířské produkce. Plzeň. Nepubl. disertační práce, ulož. na KAR FF ZČU.

- 2017a: Zlaté rouno z bronzu. Katolický vojenský př́ivěsek z bojiště u Rozvadova 1621, AZČ 12, 170-186.

- 2018: Archeologie stavovského povstání a konečného účtování, Zprávy Včely Čáslavské (v tisku).

PRCHAL, V., 2015: Společenstvo hrdinů. Válka a reprezentační strategie českomoravské aristokracie 1550-1750. Praha.

PRINCOVÁ-JUSTOVÁ, J., 2000: Chalupovský manský dvůr v Libici nad Cidlinou. Archeologický př́ispěvek k poznání středověké a raně novověké vsi Libice. Část 1, CB 7, 241-254.

PROCHÁZKA, Z., 1983: Domažličtí hrnčiři na Hořejším předměstí ve 14. a 15. století. Domažlice.

- 1990: Tillyho šance u Rozvadova. O dosud neznámé památce Tachovska, Ozvěny. Hornofalcko-český magazín, č. 2, pátek 24. srpna, 6 .

- 2009: Sklářství v Českém lese na Domažlicku a Tachovsku. Místopis skláren, brusíren a leštíren. Domažlice.

PROSTŘEDNÍK, J.-ŠÍDA, P., 2009: Záchranný archeologický výzkum pozdně středověké usedlosti s vodním dílem ve Všeni u Turnova. In: Sborník Národního památkového ústavu - územního odborného pracoviště v Liberci 2009, 147-158. Liberec.

RAYMAN, N., 2014: Městské hradby v Plané na základě archeologických výzkumů u kostela Nanebevzetí Panny Marie (okr. Tachov), AZČ 7, 121-130.

RENNER, J., 1912: Srážka u Rakovníka v r. 1620. Věstník Muzejního spolku královského města Rakovníka a politického okresu rakovnického 1 . Rakovník.

RICHTEROVÁ, J., 1981: Německá Lhota, k. o., Kamenné Žehrovice, okr. Kladno. Historie a výzkum Německá Lhota, eine mittelalterliche Ortswüstung bei Žehrovice, Bez. Kladno, AH 6, 475-479.

- 1982: Geodeticko-topografický průzkum na lokalitě Německá Lhota, okr. Kladno - Geodetisch-topographische Erkundung auf der Lokalität Německá Lhota, AH 7, 247-252. 
RING, E., 2013: Conffesionalization in the Domestic Sphere during 16th Century: Archaeology and Reformation. In: Historical Archaeology in Central Europe. Society for Historical Archaeology. Special Publication No. 10 (Mehler, N., ed.), 167-183. Rockville.

ROBERTS, M., 1956: The Military Revolution 1560-1660. An Inaugural Lecture Delivered before Queen's University of Belfast. Belfast.

RODEHROST, T., 2014: Die Schlacht bei Lutter am Barenberge im Dreißigjährigen Krieg. Ein Schlachtfeld mit offenen Fragen, Archäologie in der Niedersachsen 17, 110-113.

ROUSOVÁ, A., 2007: Das Kriegsgenre, Kriegs- und Schlachtszenen - Grundriss der Entwicklung von bildlichen Darstellungen zur Zeit des Dreißigjährigen Krieges. In: Waldstein. Albrecht von Waldstein. Inter arma silent musea? (Fučíková, E.-Čepička, L., edd.), 327-334. Prag.

ROŽMBERSKÝ, P., 1991: Kynžvartská šance, Hláska. Zpravodaj Klubu Augusta Sedláčka 2, č. 1, 9-11.

- 2010: Podnikatelé Schürerovi z Waldheimu a jejich působení v 17. století na Rokycansku, Sborník Muzea Dr. Bohuslava Horáka v Rokycanech 22, 43-67.

ROŽMBERSKÝ, P.-CHMELÍŘ, V., 2015: Příspěvky k zaniklému železářství na Radnicku, Z dějin hutnictví 43, 54-64.

SEDLÁČKOVÁ, H., 2003: Soupis lokalit s archeologickými nálezy renesančního skla (1500-1650) v Čechách a na Moravě, Historické sklo 3, 47-67.

SCHENK, Z.-MIKULÍK, J., 2014: Objev renesančních kachlů v Dobrčicích na Přerovsku, Dobrčické noviny 6 , č. $1,15-16$.

SCHIRREN, M. C., 2015: Notzeiten versteck - Metallgefässe aus dem Mühlenteich bei Gützkow. In: Krieg. Eine Archäologische Spurensuche (Meller, H.-Schefzik, M., edd.), 439-440. Halle (Saale).

SCHOLKMANN, B., 2007: Forschungsfragestellungen, Möglichkeiten und Grenzen einer Archäologie der Reformation in Mitteleuropa. In: Archäologie der Reformation. Studien zur Auswirkung des Konfessionswechsels auf die materialle Kultur. Arbeiten zur Kirchengesch. 104 (Jäggi, C.-Staecker, J., edd.), 3-25. Berlin - New York.

SCHÜRGER, A., 2007: Bleikugeln vom Schlachtfeld Lützen 1632 - Überlegungen zu Bewaffnung und Schlachtverlauf. In: Gustav Adolf. König von Schweden. Die Kraft der Erinnerung 1632-2007 (Reichel, M.-Schuberth, I., edd.), 71-80. Dößel.

- 2009: Die Schlacht von Lützen - Stumme Zeugen einer blutigen Schlacht, Archäologie in Deutschland 1, 22-25.

- 2011: Die ersten Minuten der Schlacht von Lützen (16. 11. 1632): Isolanis Kroaten und Stalhandskes finnische Reiter aus archäologischer Sicht. In: Leben und Sterben auf dem Schlachtfeld Lützen (Reichel, M.-Schuberth, I., edd.), 103-120. Lützen - Göteborg.

SCHUßMANN, M., 2014: Bomben und Granaten, Bayerische Archäologie 4, 34-37.

SIGL, J., 1995: Předstihový výzkum v Hradební ulici čp. 14 v Chrudimi v r. 1994, ZMHK 21, 61-72.

SLÁDEK, V. a kol., 2010: Sládek, V.-Laštůvková, P.-Sosna, D.-Hora, M., Martin Maxmilián z Golče. Průzkum v hrobce lorety v Golčově Jeníkově. In: Martin Maxmilián z Golče kolem 1593-1653. Císařský generál ve víru třicetileté války (Kilián, J., ed.), 200-207. České Budějovice.

SMETÁNKA, Z., 1970: Závěrečná zpráva o výzkumu - ZSO Německá Lhota (5987/70). NZ ulož. v Archivu ARÚ AV ČR.

SMETÁNKA, Z.-KLÁPŠTĚ, J., 1981: Geodeticko-topografický průzkum zaniklých středověkých vsí na Černokostelecku, PA LXXII, č. 2, 416-458.

SOUDNÁ, T.-ZIMOVÁ, R.-MATOUŠEK, V., 2010: Rytina Kolína z roku 1640 v díle Topographia Bohemiae, Moraviae et Silesiae, ASČ 14, 915-927.

STRAßBURGER, M., 2007: Spuren der Belagerung Heidelbergs im Jahr 1622 und ihre archäologische Bearbeitung, Archäologische ausgrabungen in Baden-Württemberg, 247-250.

- 2007a: Archäologische Nachweise zur Belagerung Heidelbergs im Dreißigjährigen Krieg, Archäologische Nachrichten aus Baden 74/75, 56-61.

- 2009: Haydelberga vt capitur. Archäologie der Belagerungen Heidelbergs im 17. Jahrhundert, Militär und Gesellschaft in der Frühen Neuzeit 13, Heft 1, 143-146.

SUTHERLAND, T., 2005: Battlefield Archaeology - A Guide to the Archaeology of Conflict. Bradford.

SYMONDS, J.-VAŘEKA, P. (edd.), 2016: Paysans et soldats. Archaeologie des villages de Boheme abandonnes durant la guerre de trente Ans. In: Violences de Guerre, violences de masse (Guilaine, J.-Semelin, J., edd.), 129-145. Paris.

ŠÁMAL, Z., 2018: Bojiště u Rakovníka 1620. Př́́spěvek k problematice detektorové prospekce raně novověkých. Nepubl. bakalářská práce, ulož. v Ústavu pro pravěk a ranou dobu dějinnou FF UK. 
ŠEBELA, L.-VANĚK, J., 1985: Hromadný nález ze studny v areálu bývalého bratrského sboru v Ivančicích. Přelom 16. a 17. století. Ivančice.

ŠIKULOVÁ, V., 2004: Habánské umyvadlo Jana Jiřího Krnovského nalezené v Opavě, Opava. Sborník $\mathrm{k}$ dějinám města $4,19-28$.

ŠIMÁK, J. V., 1922/1923: Ohledání ostatků Albrechta z Valdštejna a jeho př́íbuzných v Mnichově Hradišti, PA XXXIII, 153-158.

ŠREJBROVÁ, J. (ed.), 2018: Svět kachlových kamen. Kachle a kachlová produkce severozápadních Čech. Most.

TIŠEROVÁ, R., 2015: Archeologický výzkum barokní zahrady na Lemberku: strategie, průběh výzkumu a dosavadní poznatky, Fontes Nissae. Prameny Nisy XVI, č. 2, 94-111.

- 2016: Archeologický výzkum barokní zahrady na Lemberku: studium environmentu, Fontes Nissae. Prameny Nisy XVII, č. 2, 88-103.

TIŠEROVÁ, R.-STARÁ, M., 2007: Stolní keramika Valdštejnova venkova. In: Valdštejn. Albrecht z Valdštejna. Inter arma silent musae? (Fučíková, E.-Čepička, L., edd.), 254-258. Praha.

TIŠEROVÁ, R. (ed.), 2018: Frýdlantský poklad. Archeologický výzkum Zámeckého rybníka ve Frýdlantu. Liberec.

TÖRÖK, J., 2011: Posouzení a průzkum militárií a ostatních kovových nálezů z bojiště roku 1621 u Rozvadova v rámci konzervace, Sborník Muzea Českého lesa v Tachově 32, 21-23.

ULIČNÝ, P., 2007: Zahrada Valdštejnova casina u Jičína. In: Valdštejn. Albrecht z Valdštejna. Inter arma silent musae? (Fučíková, E.-Čepička, L., edd.), 239-244. Praha.

ULRYCHOVÁ, E., 2010: Dýmky z valdštejnského období z Jičína a Hořic, ASČ 14, 929-932.

VAŘEKA, P., 2003: Výrobní (hrnčířský?) areál z časného novověku v Berouně - České ulici čp. 56, Archeologia technica 15, 78-84.

- 2006: Aldašín. Nepubl. nálezová zpráva uložená v Archivu ARÚ AV ČR.

- 2009: Zaniklá stř̌edověká vesnice Vojkov na Černokostelecku - svědectví archeologie, Kuděj 11, č. 1, $43-54$

- 2010: Zaniklá středověká a raně novověká vesnice Vojkov na Černokostelecku - nedestruktivní výzkum, Acta Fakulty filozofické Západočeské univerzity v Plzni, č. 4, 147-181.

- 2014: Zaniklá středověká a časně novověká ves Rovný na Zbirožsku (okr. Rokycany), AZČ 7, 131-143.

- 2016: Zaniklá středověká a časně novověká vesnice Bukov na Zbirožsku (okr. Rokycany), AZČ 10, $156-167$.

VAŘEKA, P. a kol., 2006: Archeologie zaniklých středověkých vesnic na Rokycansku I. Plzeň.

VELEMÍNSKÝ, P.-DOBISÍKOVÁ, M.-KUŽELKA, V., 2000: Antropologický průzkum kostry generála J. Sporcka, Živa 48, č. 1, 39-40.

- 2001: Příbuznost a morfologie u kosterních pozůstatků rodiny Sweerts-Spork, Sborník české společnosti antropologické 48, 156-159.

VESELÁ, L., 2005: Knihy na dvoře Rožmberků. Praha.

- 2013: Knihy z českých zemí ve švédských knihovnách (K výzkumu knihovny Becků z Leopoldsdorfu), Knihy a Dějiny 2011/2012, 18/19, 93-96.

- 2014: Budovcův exempláŕ knihy Symphonia catholica v Univerzitní knihovně v Lundu. Humanismus v rozmanitosti pohledů. In: Farrago festiva Iosepho Hejnic nonagenario oblata, 393-399. Praha.

VESELÁ, R., 2006: Zaniklá ves Cetkov. In: Vařeka, P. a kol., Archeologie zaniklých středověkých vesnic na Rokycansku I., 67-98. Plzeň.

VLČEK, E., 1976: Diagnóza zdravotního stavu Albrechta z Valdštejna stanovená na základě nejnovějšího průzkumu jeho kosterních pozůstatků, Časopis lékařství českého 115, 678.

- 1993: Jak zemřeli. Významné osobnosti českých dějin z pohledu antropologie a lékařství. Praha.

VONDRÁČKOVÁ, K., 1996: Nález ze středověkých studní pod jezuitským kostelem v Klatovech, SZM historie 13, 134-159.

VYČÍSLÍK, A., 1974: Vojenské památky Bratislavy. Bratislava.

VYŠOHLÍD, M., 2015: Hrnčířské předměstí v Berouně: První etapa archeologického výzkumu na parcele ppč. 296, ASČ 19, 411-430.

VYŠOHLÍD, M.-ZAVŘEL, J., 2016: Souvrství povodňových a antropogenních uloženin z Hrnčířského předměstí v Berouně, Český kras 42, 41-48.

WALDE, O., 1916-1920: Storhetstidens litterära krigsbyten 1-2. Uppsala.

WALDHAUSER, J., 2009: Archeologická tajemství Mladé Boleslavi. Liberec.

WALDHAUSER, J., 2009a: Švédský vojenský tábor ze třicetileté války na katastrech Staré Boleslavi (okr. Praha-východ) a Hlavence (okr. Mladá Boleslav), ASČ 13, 939-964. 
WANGERIN, E., 1986: Ein Massengrab aus der Zeit des Dreißigjährigen Krieges in Höchstadt a. d. Aisch, Das Archäologische Jahr in Bayern 1985, 157-159.

ZELENKA, A., 2016: Bezdružice (okr. Tachov). Příspěvek k raně novověkému vývoji poddanského města, AZČ 10, 213-229.

ZUMAN, F., 1931: Švédský tábor u Staré Boleslavi, Ročenka Okresní jednoty musejní v Brandýse nad Labem, 5-17.

ŽÁKOVSKÝ, P., 2011: Středověká a raně novověká militaria ze sbírek Lovecko-lesnického muzea v Úsově na Moravě, Acta Militaria Mediaevalia 7, 105-159.

ŽÁKOVSKÝ, P.-DRNOVSKÝ, P., 2017: Nález barokního kordu z Habřiny na Jaroměřsku ve východních Čechách - Der Fund des Barockdegens aus Habřina in der ostböhmischen Region Jaroměr̆, AH 42, 279-295.

ŽÁKOVSKÝ, P.-SCHENK, Z., 2017: Středověké a raně novověké zbraně Přerovska. Zbraně a zbroj od kolapsu Velké Moravy do konce třicetileté války. Brno - Přerov.

ŽEGKLITZ, J., 2007: Renaissance glassworks Broumy, Studies in Post-Medieval Archaeology 2, 145-180.

- 2007a: Renesanční sklářská hut’ v Broumech. Muzejní a vlastivědná práce, ČSPS 45/115, č. 2, $118-126$.

- 2012: Prints and other artwork models for motifs on stove tiles from the Czech lands. Renaissance stove tiles as a means for disseminating ideas and culture during the age of Reformation, Studies in Post-Medieval Archaeology 4, 25-111.

- 2013: Archaeology of the Modern Period in the Czech Territories: A Long Tradition and Long Beginnings. In: Historical Archaeology in Central Europe. Society for Historical Archaeology. Special Publication No. 10 (Mehler, N., ed.), 53-69. Rockville.

- 2015: K počátkům tzv. malhornware v Čechách. In: V za(u)jetí malostranských stratigrafií. Sborník k životnímu jubileu Jarmily Čihákové (Podliska, J., ed.), 110-123. Praha.

ŽEGKLITZ, J.-HAZLBAUER, Z.-CHOTĚBOR, P., 1992: Pokus o rekonstrukci kachlových kamen ze zaniklé renesanční sklárny v Broumech, AR XLVI, 94-108.

\section{Zusammenfassung}

Historisch-archäologische Erforschung der Zeit des Dreißigjährigen Krieges (1618-1648). Derzeitiger Stand und Perspektiven des Studiums

Parallel zur Formung einer New Military History in den historischen Wissenschaften kommt es in der Archäologie zur Etablierung einer Conflict Archaeology. Beide Strömungen basieren auf dem Konzept einer „Militärrevolution“, welche die Attraktivität der gegenwärtigen modernen Geschichte und Archäologie des Militärwesens besonders in den beobachteten Machtverhältnissen steigert, die als politische, religiöse, kulturelle Dominanz und Resistance zum Ausdruck gebracht werden können. Traditionelle Beschreibungen der direkten operativen Geschichte (z.B. Schlachten, Manöver, Strategien) werden durch das Studium weiter gefasster Aspekte des Krieges aus ökonomischer (Produktion, Tausch, Bedarf), ideologischer (Moral, Ästhetik), militärischer (Aggression, Defensive) und politischer (Zentralisierung, Institutionalisierung und territoriale Verankerung sozialer Beziehungen) Sicht ersetzt. Der Krieg wurde ein Mittel zur Störung und Änderung bestehender sozialer und kultureller Strukturen. Diese lassen sich besonders dank den Untergangshorizonten beobachten, durch welche die Zeit in davor (ante quem) und danach (post quem) unterteilt wird. Es eröffnet sich nicht nur ein neuer Weg, um traditionelle Themen aus einem anderen Blickwinkel nachzuvollziehen, sondern auf Grundlage einer Interaktion zwischen historischen und archäologischen Quellen studiert man auch den Alltag aller sozialer Schichten (Tab. 1). Das Beispiel von den Dreißigjährigen Krieg betreffenden lokalen Studien beginnt im Endergebnis dazu beizutragen, nicht nur regionale, sondern auch globale Probleme der ersten Hälfte des 17. Jahrhunderts zu klären. Das macht aus der Archäologie des Dreißigjährigen Krieges nicht nur in Tschechien, sondern auch im breiteren europäischen Rahmen einen wichtigen Bestandteil der Archäologie der Neuzeit (Karte 1).

Einen großen Gewinn hat die Etablierung der „Archäologie der Schlachtfelder“ (Karte 2). In Tschechien wurde bisher den Schlachten bei Rakovník 1620, am Weißen Berg bei Prag 1620, 
bei Rozvadov 1621, der Schlacht bei Triebl 1647 und bei Tepl 1647 archäologisch Aufmerksamkeit gewidmet. Beachtung geschenkt wird Feldbefestigungen, die auf Schlachtfeldern oder zur Sicherung strategischer Verkehrswege entstanden. Ein wichtiger Bestandteil der Forschung ist das Auffinden von Orten, an denen die Gebeine der Kriegsakteure ruhten. Die erste Gruppe bilden Funde aus Massengräbern und Einzelgräbern anonymer Soldaten. Gräber wurden erfasst in Písek 1619, bei Kralovice 1620, auf dem Weißen Berg 1620 und in Tábor 1621. Gräberfelder von angeblich schwedischen Soldaten aus dem Jahr 1548 wurden in Prag entdeckt. Außer auf Untersuchungen von Massengräbern orientiert sich die Forschung auf die Gebeine von bedeutende Persönlichkeiten, Herrschern und Heerführern. In Böhmen reicht die Tradition der anthropologischen Forschung sogar bis in die zwanziger Jahre des 20. Jahrhunderts zurück, als die ersten Untersuchungsergebnisse der Gebeine von Albrecht von Wallenstein veröffentlicht wurden, dessen Körper in Mnichovo Hradiště ruhte. Ferner wurden die Gebeine von Jean Louis Raduit de Souches in Brno, von Johann von Sporck, dem kaiserlichen General in Kuks, und von Martin Maximilian von der Goltz in Golčův Jeníkov untersucht.

Eine weitere Forschungsrichtung ist die Siedlungsarchäologie (Karte 3). Die Erforschung von Städten beschäftigt sich unter dem Einfluss der Baugeschichte mit dem Wandel des „oberirdischen" Aussehens von Städten und ist insbesondere auf Erkenntnisse zu Befestigungssystemen, dem Wachstum von Palästen und zur Restrukturalisierung der Kirchenarchitektur ausgerichtet. Eine weitere zielt direkt auf Untergangshorizonte ab, die besonders von völlig zerstörten Häusern und Häusertrakten und aus dem handwerklichen Hinterland u.ä. stammen. In Anknüpfung an die traditionelle Erforschung der ländlichen Umgebung im Mittelalter begann ab den siebziger Jahren des 20. Jahrhunderts die Erforschung der ländlichen Umgebung in der frühen Neuzeit einen Aufschwung zu erleben, die erste Fundstelle war Německá Lhota. Anschließend ist die Erforschung von Dorfwüstungen im Gebiet von Schwarzkosteletz angelaufen. Ab den neunziger Jahren des 20. Jahrhunderts kamen langsam noch weitere über Böhmen und Mähren verstreute Einzelheiten hinzu. In den letzten Jahren wird der Erforschung der Mikroregionen in den Gebieten um Rokycany und Chrudim eine systematische Aufmerksamkeit gewidmet.

Der Dreißigjährige Krieg bildete den Höhepunkt der im 16. Jahrhundert entfachten Religionsstreite. In Südmähren wird der Erforschung der häretischen Gruppe der Wiedertäufer, bzw. Habaner langfristig Aufmerksamkeit gewidmet. In den Böhmischen Ländern haben ab dem Jahr 1457 die Böhmischen Brüder gewirkt. Als international bedeutende archäologische Forschung kann man die Untersuchung in der Feste von Kralice ansehen, wo die geheime Druckerwerkstatt aus den Jahren 1562 bis 1619 untersucht wurde, in der die Mährischen Brüder die Kralitzer Bibel gedruckt haben.

Ein weiteres Kapitel beschäftigt sich mit der Erforschung der Umstrukturierung der Machtstrukturen in den Böhmischen Ländern, als die siegreiche Partei bestrebt war, ihre neue gesellschaftliche Stellung in dem eroberten Gebiet zu legitimieren. Dabei geht es um die Errichtung oder Rekonstruktion von Palästen, Burgen, Stadtbefestigungen. Die Kriegsereignisse haben in den Böhmischen Ländern deutlich zum Wandel der Wirtschaft beigetragen. Während es bei einigen Handwerken zu einer Rezession kam, begannen andere aufzublühen. Über die Beobachtung ausgewählter Handwerke wie Töpferei, Ofenbau, Glasbläserei oder metallverarbeitende Handwerke werden ökonomische Veränderungen betrachtet, die der Krieg mit sich brachte. Im Kontext des Studiums des Waffenwesens entfaltet sich auch die Erforschung von Waffen, Rüstungen und weiterer militärischer Artefakte.

Die abschließende Abhandlung des Beitrages ist Depots und Schätzen gewidmet (Karte 4). Auf dem Gebiet Tschechiens geht es dabei schätzungsweise um mehr als 350 Beispiele. Eine selbständige Gruppe von Artefakten, der die Geschichte und die Archäologie Aufmerksamkeit widmen, sind Kollektionen von Wertsachen und Kuriositäten, die von den schwedischen Truppen nach Skandinavien mitgenommen wurden. Dabei geht es besonders um Gegenstände aus der Kunstkammer von Rudolf II. von Habsburg.

Der gelieferte Überblick über den Stand und die Entwicklung der historisch-archäologischen Erforschung des Dreißigjährigen Krieges deutet besonders ab den neunziger Jahren des 
20. Jahrhunderts darauf hin, dass es in Europa und auch in Tschechien eine Fülle an Interessensobjekten, Themenkreisen und Denkmälern gibt, die in naher Zukunft eine größere Aufmerksamkeit verdienen. Das riesige Potenzial birgt in sich die Bildung internationaler Forscherteams, welche die positiven und negativen Folgen des Krieges in den verschiedenen Ländern miteinander vergleichen können.

Der vorliegende Beitrag wurde gefördert von dem Förderprojekt GAČR: GA15-03380S: Wandel des Landes. Interdisziplinäre Erforschung des Einflusses des Dreißigjährigen Krieges auf die ländlichen Regionen Böhmens (2015-2017).

Mgr. et Mgr. Michal Preusz, Ph.D., Katedra archeologie Filozofické fakulty Západočeské univerzity v Plzni, Sedláčkova 15, 30614 Plzeň, Česká republika 
